\title{
LATE QUATERNARY CHRONOLOGY AND STRATIGRAPHY OF TWELVE SITES ON KAUA'I
}

\author{
David A Burney \\ Department of Biological Sciences, Fordham University, Bronx, New York 10458, USA. Email: burney@ fordham.edu.
}

\begin{abstract}
Twelve new sites on Kaua'i provide an island-wide view of late Quaternary (near time) environments on the oldest of the major Hawaiian Islands. Radiocarbon-dated lithologies are compared for estuarine sites on windward and leeward coasts, interior peat bogs ranging from 169 to $1220 \mathrm{~m}$ in elevation, prehistoric fishponds, and a sinkhole paleolake in the Maha'ulepu cave system. Terrestrial sedimentation begins in many coastal sites about $6000 \mathrm{cal} \mathrm{BP}$, as sea level approached modern levels. Prehuman sedimentation rates were quite low in all these sites, generally $<2 \mathrm{~mm} / \mathrm{yr}$, although coastal sites in the late Holocene were subject to major episodic sediment influx from extreme events, including tsunamis, hurricanes, and floods. Interior sites are generally older, having accumulated humic clay and peat layers at least since the late Pleistocene. Since the arrival of humans less than two millennia ago, sedimentation rates have increased in some coastal sites, and further local increases (as much as two orders of magnitude) have occurred since European arrival. Evidence from sites containing fossils of extinct terrestrial snails is consistent with the hypothesis that human-caused extinctions have proceeded in three phases, corresponding to losses (generally the largest species) occurring soon after the arrival of the first humans, followed by a second wave of extinction in late prehistoric times, and a third after European colonization. Dating of sediments from fishponds constructed or enhanced by prehistoric Polynesians suggests that this early form of aquaculture was initiated on Kaua' $i$ by about $830 \pm 50 \mathrm{BP}$. The most elaborate example of fishpond construction in the Hawaiian Islands, the Alekoko or Menehune fishpond on Kaua'i's southeast coast, was probably undertaken by $580 \pm 30 \mathrm{BP}$.
\end{abstract}

\section{INTRODUCTION}

Kaua ' $i$, the northernmost and oldest of the major Hawaiian Islands, abounds with sites of potential interest for late Quaternary studies. Few of these, however, have been investigated previously. Until now, there has been no attempt to make an island-wide synthesis of information from an array of radiocarbon-dated sites. The only comprehensive studies of Kaua'i paleoenvironments, consisting of coring sites in the Alakai Swamp of Kaua 'i's humid highlands, were the exhaustive pollen studies of Selling (1948). This was before the advent of ${ }^{14} \mathrm{C}$ dating, so the marked changes within the sediment profiles and pollen spectra that he noted have been a matter of speculation ever since (e.g., Gavenda 1997) although comparisons to a well-dated core from montane East Maui (Burney et al. 1995) provided some clarification: pollen and sedimentology of Flat Top Bog at $2200 \mathrm{~m}$ on the Haleakala volcano indicates a dry early Holocene, followed by a wet phase between about $5800 \mathrm{BP}$ and $2200 \mathrm{BP}$, and variable conditions since.

Studies of extinct fossil birds on Kaua 'i (e.g. Olson and James 1991, 1997; James and Olson 1991) have revealed a remarkable Holocene avifauna, including large flightless waterfowl, a bird-catching owl, and numerous honeycreepers (Fringillidae: Drepanidini). Until recently, however, these were known only from undated specimens from the Makawehi Dunes on the south coast. Associated terrestrial invertebrate shells were dated to $6740 \pm 80$ and $5145 \pm 60 \mathrm{BP}$ (Olson and James 1982), in fair agreement with a single bone date of $4690 \pm 100 \mathrm{BP}$ (Hearty et al. 2000) on the extirpated but reintroduced Hawaiian Goose (Branta sandvicensis). The carbonate sand matrix yielded an age about twice that of the goose, at $8900 \pm 70 \mathrm{BP}$, and whole-rock amino acid racemization data from the site suggests a Holocene age (Hearty et al. 2000).

Archaeological data on Kaua ' $\mathrm{i}$ is also thinly dated. The relevance to earliest human settlement of ${ }^{14} \mathrm{C}$ ages from the seventh to eighth century AD on charcoal and buried soil horizons dubiously associated with early sites on the north coast has subsequently been questioned on the basis of follow-up studies (reviewed in Kirch 1985:87). Many other human sites have been dated, but most are only a few centuries old, and all lack clear associations with extinct fauna or other evidence suggesting that they belong to the earliest phase of Polynesian settlement. At another north coast occupation site, 
Dixon et al. (1997) dated human evidence (charcoal in a hearth) and a nearby natural deposit of shells of a large extinct land snail (Carelia dolei isenbergi), showing a discrepancy between them of about $900{ }^{14} \mathrm{C}$ yr and therefore no evidence of temporal overlap.

Burney et al. (2001) report a new fossil site, the sinkhole paleolake in the Maha'ulepu Cave system on the south coast. Its rich record of the Holocene brings many questions regarding Kaua 'i's prehistoric past into sharper focus thanks to a varied lithology and well-preserved biostratigraphy. A multidisciplinary team has analyzed the site for sedimentology, pollen, plant macrofossils, diatoms, vertebrate bones, invertebrate shells, and human artifacts, and produced a chronology based on $33{ }^{14} \mathrm{C}$ dates, the majority using accelerator mass spectrometry (AMS). Testing of old hypotheses and generation of new ones has been made possible by this extraordinary site, the only limitation being that caution is in order for inferences concerning the entire island from a single site. For that reason, I offer here the first data from 11 other sites from a variety of settings throughout the island, as well as additional dates for Maha 'ulepu. Although the data base for these other sites is limited primarily to lithological description and preliminary ${ }^{14} \mathrm{C}$ dating, this geographically and taphonomically expanded data set sheds considerable light on unresolved questions raised by the rich yield of data from Maha 'ulepu. At the landscape level, answers will be sought in the following areas: 1) determination of the age of previously undated coastal estuaries, peat bogs, extinct land snail fossil sites, and prehistoric Polynesian fishponds; 2) evaluation of the extent and timing of episodic extreme sedimentation events in coastal areas and inference of their cause or causes; and 3) comparison of the characteristics and rates of sedimentation in prehuman vs. Polynesian and European phases. This work provides a framework for studies of the charcoal and pollen stratigraphy of these sites now underway.

\section{METHODS}

Sites were selected for analysis following a preliminary survey of all known locations with potential for recovery of late Quaternary sediments. Included were coastal estuaries, crater swamps, peat bogs, caves, and prehistoric fishponds presumably constructed or enhanced by humans. Survey work included inspection of topographic and geological maps, use of infrared color aerial photographs, ground evaluation, and where feasible, subsurface sampling. The primary tool for the latter was an open-sided bucket auger of the "mud head" type, $7.5 \mathrm{~cm}$ in diameter. This allows rapid collection of a minimally disturbed stratigraphic sample that can be quickly described and subsampled in the field.

Several sites showing promise in terms of sediment stratification and microfossil preservation were subsequently sampled with a Livingstone sampler piston-corer, using thin-walled PVC pipe of nominal 2 inch $(5 \mathrm{~cm})$ diameter for core barrels. Harder substrates were sampled with nominal 1.5 inch $(3.75 \mathrm{~cm})$ diameter stainless-steel pipe, driven when necessary with a sliding drop-hammer for extra force. Sites showing potential for macrofossil recovery, when not covered with water, were excavated with grid control. Above the water table, excavation was by natural layers with three-dimensional plotting of significant human artifacts. The Maha'ulepu Cave paleolake site was excavated below the water table with grid control in $10 \mathrm{~cm}$ lifts. Gas-powered water pumps were used to generate a temporary cone of depression around a PVC-cased sump hole (see Burney et al. 2001, for details).

Sediments were described in terms of texture, inclusions, Munsell wet color, and structure. In the lab, wet mounts of sediments were examined under the microscope at 30×, 100×, and 400×. Determinations of water-column $\mathrm{pH}$, specific conductance, dissolved $\mathrm{O}_{2}$, and temperature were employed 
when additional information was needed to characterize the sedimentary environment. Mollusc shell identifications were made from Christensen (1992) and by comparison with reference collections housed at the Bernice P Bishop Museum in Honolulu and other collections belonging to private collectors on Kaua' $i$. For details concerning other macrofossils and human artifacts, see Burney et al. (2001).

Because additional work is planned for many of these sites, particularly attempts to reach even deeper layers, stratigraphy is described here from the modern surface downwards (reverse chronological order). At Maha'ulepu, where Burney et al. (2001) published a more comprehensive description down to basal rock, layers will be described from the base upward in chronological order.

Bulk sediment dates were from material picked for rootlets and pretreated with hot $\mathrm{HCl}$ to remove carbonates, followed by $\mathrm{NaOH}$ to remove secondary organic acids, and a second $\mathrm{HCl}$ treatment. This is the "humin" fraction, primarily pollen, spores, microscopic charcoal, and plant fibers. Plant macrofossils were dated by preference whenever available, and were given the same pretreatments. Bones were treated with cold dilute $\mathrm{HCl}$ to remove the apatite fraction, followed by $\mathrm{NaOH}$ to remove soluble organics ("humates"). Shells were subjected to $\mathrm{HCl}$ etches to remove secondary carbonate components. Land snail shells were inspected by SEM and subjected to protein analysis to determine their suitability. Bones were evaluated for $\mathrm{C}: \mathrm{N}, \% \mathrm{C}$ and collagen condition, and rejected if there was evidence for poor preservation or contamination. All dates are corrected for isotopic fractionation, and reported in radiocarbon years before present $\pm 1 \sigma(\mathrm{BP})$, followed by the calibrated range at $2 \sigma$ (cal BP or cal AD), based on INTCAL98 (Stuiver et al. 1998).

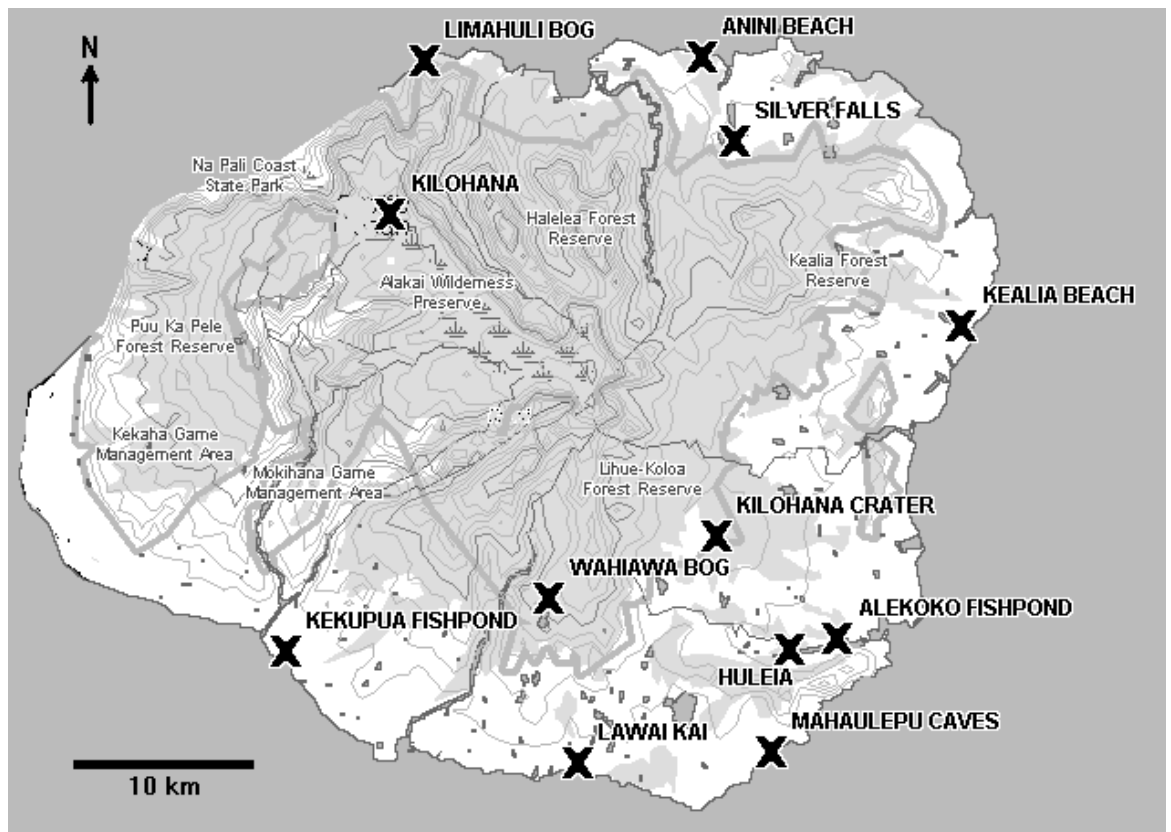

Figure 1 Location of new ${ }^{14} \mathrm{C}$ dated sites on Kaua' $\mathrm{i}$ in the Hawaiian Islands

\section{RESULTS AND DISCUSSION}

Sites analyzed (Figure 1 above, Table 1) include coastal estuaries from both the wet (1600-2000 $\mathrm{mm} / \mathrm{yr})$ windward northern coast and the drier $(\leq 1000 \mathrm{~mm} / \mathrm{yr})$ leeward southern coast. In the inte- 
Table 1 New paleoecological sites from Kaua ${ }^{i} i$

\begin{tabular}{|c|c|c|c|c|}
\hline Site & $\begin{array}{l}\text { Latitude/longitude/ } \\
\text { elevation }\end{array}$ & Type & How sampled ${ }^{\mathrm{a}}$ & Oldest ${ }^{14} \mathrm{C}$ date ${ }^{b}$ \\
\hline Alekoko Fishpond & $\begin{array}{l}\mathrm{N} 21^{\circ} 57^{\prime} 07^{\prime \prime} / \mathrm{W} 159^{\circ} 22^{\prime} 34^{\prime \prime} \\
0 \mathrm{~m}\end{array}$ & $\begin{array}{l}\text { Prehistoric } \\
\text { fishpond/estuary }\end{array}$ & Core $(3.5 \mathrm{~m})$ & $\begin{array}{l}3230 \pm 70 \mathrm{BP} \\
3620-3340 \mathrm{cal} \mathrm{BP}\end{array}$ \\
\hline Anini Beach & $\begin{array}{l}\mathrm{N} 22^{\circ} 13^{\prime} 34^{\prime \prime} / \mathrm{W} 159^{\circ} 27^{\prime} 09^{\prime \prime} \\
2 \mathrm{~m}\end{array}$ & Flood plain & Excavation & $\begin{array}{l}1840 \pm 50 \mathrm{BP} \\
70-260,290-320 \mathrm{cal} \mathrm{AD}\end{array}$ \\
\hline Huleia Valley & $\begin{array}{l}\mathrm{N} 21^{\circ} 56^{\prime} 49^{\prime \prime} / \mathrm{W} 159^{\circ} 24^{\prime} 01^{\prime \prime} \\
2 \mathrm{~m}\end{array}$ & Flood plain & 6 cores $(3.6 \mathrm{~m})$ & $\begin{array}{l}2790 \pm 40 \mathrm{BP} \\
2970-2780 \mathrm{cal} \mathrm{BP}\end{array}$ \\
\hline Kealia Beach & $\begin{array}{l}\mathrm{N} 22^{\circ} 05^{\prime} 51^{\prime \prime} / \mathrm{W} 159^{\circ} 18^{\prime} 40^{\prime \prime} \\
2 \mathrm{~m}\end{array}$ & Estuary & Excavation & $\begin{array}{l}1290 \pm 50 \mathrm{yr} \text { BP } \\
650-870 \mathrm{cal} \mathrm{AD}\end{array}$ \\
\hline Kekupua Fishpond & $\begin{array}{l}\mathrm{N} 21^{\circ} 56^{\prime} 46^{\prime \prime} / \mathrm{W} 159^{\circ} 39^{\prime} 14^{\prime \prime} \\
2 \mathrm{~m}\end{array}$ & Prehistoric fishpond & Core $(2.2 \mathrm{~m})$ & $\begin{array}{l}980 \pm 80 \mathrm{BP} \\
895-1225 \mathrm{cal} \mathrm{AD}\end{array}$ \\
\hline Kilohana (Alakai) & $\begin{array}{l}\mathrm{N} 22^{\circ} 09^{\prime} 28^{\prime \prime} / \mathrm{W} 159^{\circ} 35^{\prime} 56^{\prime \prime} \\
1220 \mathrm{~m}\end{array}$ & Montane bog & Core $(3.2 \mathrm{~m})$ & $\begin{array}{l}15,100 \pm 80 \mathrm{BP} \\
18,525-17,625 \text { cal BP }\end{array}$ \\
\hline Kilohana Crater & $\begin{array}{l}\mathrm{N} 22^{\circ} 00^{\prime} 02^{\prime \prime} / \mathrm{W} 159^{\circ} 25^{\prime} 42^{\prime \prime} \\
243 \mathrm{~m}\end{array}$ & Crater swamp & Core $(2.0 \mathrm{~m})$ & $26,020 \pm 230 \mathrm{BP}$ \\
\hline Lawai Kai & $\begin{array}{l}\mathrm{N} 21^{\circ} 53^{\prime} 35^{\prime \prime} / \mathrm{W} 159^{\circ} 30^{\prime} 26^{\prime \prime} \\
1 \mathrm{~m}\end{array}$ & $\begin{array}{l}\text { Prehistoric } \\
\text { fishpond/estuaryc }\end{array}$ & 2 cores $(6.5 \mathrm{~m})$ & $\begin{array}{l}5300 \pm 80 \mathrm{BP} \\
6280-5910 \mathrm{cal} \mathrm{BP}\end{array}$ \\
\hline Limahuli Bog & $\begin{array}{l}\mathrm{N} 22^{\circ} 13^{\prime} 31^{\prime \prime} / \mathrm{W} 159^{\circ} 34^{\prime} 37^{\prime \prime} \\
2 \mathrm{~m}\end{array}$ & Flood plain & Core $(6.2 \mathrm{~m})$ & $\begin{array}{l}8420 \pm 70 \text { BP } \\
9535-9280 \text { cal BP }\end{array}$ \\
\hline Maha'ulepu Caves & $\begin{array}{l}\mathrm{N} 21^{\circ} 53^{\prime} 30^{\prime \prime} / \mathrm{W} 159^{\circ} 25^{\prime} 17^{\prime \prime} \\
2 \mathrm{~m}\end{array}$ & Cave system/paleolake & $\begin{array}{l}3 \text { excavations, } 20 \text { cores } \\
(9.5 \mathrm{~m})\end{array}$ & $\begin{array}{l}8520 \pm 80 \mathrm{BP} \\
9580-9425 \mathrm{cal} \mathrm{BP}\end{array}$ \\
\hline Silver Falls & $\begin{array}{l}\mathrm{N} 22^{\circ} 10^{\prime} 37^{\prime} / \mathrm{W} 159^{\circ} 25^{\prime} 21^{\prime \prime} \\
169 \mathrm{~m}\end{array}$ & Montane bog & 2 cores $(3.6 \mathrm{~m})$ & $\begin{array}{l}8160 \pm 40 \mathrm{BP} \\
9250-9010 \mathrm{cal} \mathrm{BP}\end{array}$ \\
\hline Wahiawa Bog & $\begin{array}{l}\mathrm{N} 21^{\circ} 58^{\prime} 35^{\prime \prime} / \mathrm{W} 159^{\circ} 30^{\prime} 35^{\prime \prime} \\
665 \mathrm{~m}\end{array}$ & Montane bog & Core $(4.9 \mathrm{~m})$ & $23,090 \pm 180 \mathrm{BP}$ \\
\hline
\end{tabular}

aParenthetical numbers following number of cores indicate maximum depth reached below surface.

${ }^{b}$ Dates given in radiocarbon years (yr BP) $\pm 1 \sigma$, followed by calibrated range at $2 \sigma$ (cal yr BP or AD). Calibrations, where available, are from Stuiver et al. (1998).

"Sites designated "prehistoric fishpond/estuary" appear from sedimentary and geomorphological context to be natural estuaries modified by humans. 
rior, peat bogs and a crater swamp provide information on sites ranging from $169 \mathrm{~m}$ to $1220 \mathrm{~m}$ in elevation. All of these receive higher precipitation than the leeward lowlands, and Alakai Swamp receives about twice as much rainfall as the windward coast (Armstrong 1983). Fishpond sites included are all on the southern and SE coast, and all but one (Kekupua) show evidence that they were natural sedimentary basins in prehuman times that were enhanced by prehistoric construction of retaining walls. The sinkhole paleolake in the cave system at Maha'ulepu on the south coast is a composite of several types of sedimentary features: it is a limestone cave with an open sinkhole that contained a lake throughout most of the Holocene. Maha'ulepu was probably used as a prehistoric fishpond, and is low and close enough to the sea to receive estuarine sediments especially during extreme marine events such as hurricanes and tsunamis.

\section{Coastal Sites, Windward to Leeward}

\section{Limahuli Bog}

Limahuli Bog is more properly a fen, as some water flows through it. The small wetland is seaward of the entrance to Limahuli Gardens on Kaua 'i's north shore. It is bounded on the south by the roadbed of Highway 56, which is located on the edge of the lowest part of the slope forming the east wall of Limahuli Valley. The Limahuli River skirts the edge of the wetland on the SW side, but this area has been modified by ditching and filling to accommodate the development of the road and home construction in the area. Presently an artificial ditch drains water westward from the seaward side of the wetland, but the original condition probably involved natural damming by the large coastal dunes on the north side, with drainage of the wetland most likely integrated with the outlet of the Limahuli River. In addition to the changes in drainage effected by artificial ditching in the area, the topography surrounding the mouth of the river, including the site, was modified by the coarse clastics deposited on 1 April 1946 (M Soppeland, personal communication), by the largest historicallyknown tsunami on this coast.

The bog surface is covered with a thick growth of ferns, grasses, and sedges. These are growing out of an unconsolidated mat of plant debris, mostly graminoid leaves and fern stems, that has accumulated up to the water surface. The surface water of the bog is fresh and neutral. The stream draining westwards from the north side had a specific conductance of $314 \mu \mathrm{mhos} / \mathrm{cm}, \mathrm{a} \mathrm{pH}$ of 7.11 , and a temperature of $22.8^{\circ} \mathrm{C}$ when measured at noon on 8 June 1999 . Water in a hole cut in the peat for coring was $485 \mu \mathrm{mhos} / \mathrm{cm}$ conductivity, $7.07 \mathrm{pH}$, and $25.7^{\circ} \mathrm{C}$ temperature.

Throughout the site, we systematically probed the subsurface layers with a thin steel rod. Along the north side, there is a layer of gravelly sand about $50 \mathrm{~cm}$ below the bog surface that wedges out about $50 \mathrm{~m}$ into the wetland, giving way southwards to a thick deposit of coarse peat. Near the center of the wetland, at the site selected for piston-coring, a thin steel rod penetrated easily to $4 \mathrm{~m}$ depth. The unconsolidated plant detritus in the surface layer was too soft and fibrous to extract by coring. At $189 \mathrm{~cm}$ below the bog surface, sediment became dense enough for coring. Below that level, recovery was essentially $100 \%$, except for about $50 \mathrm{~cm}$ of material in a layer containing tree trunks, in which sediment recovery was impeded by a dense plug of wood in the bottom of the core pipe. Coring reached a depth of $615 \mathrm{~cm}$ below the bog surface (Figure 2; see Appendix 1 for dates and Appendix 2 for core description).

Limahuli contains a record of both terrestrial and marine events of the Holocene lowlands. The silt, sand, and gravel layers near the base of the core suggest that this site was part of the flood plain of the Limahuli River in the early Holocene, receiving coarse sediments intermittently during flooding events. By about 5500 BP (about $6000 \mathrm{cal} \mathrm{BP),} \mathrm{however,} \mathrm{rising} \mathrm{sea} \mathrm{level} \mathrm{produced} \mathrm{a} \mathrm{more} \mathrm{perma-}$ 


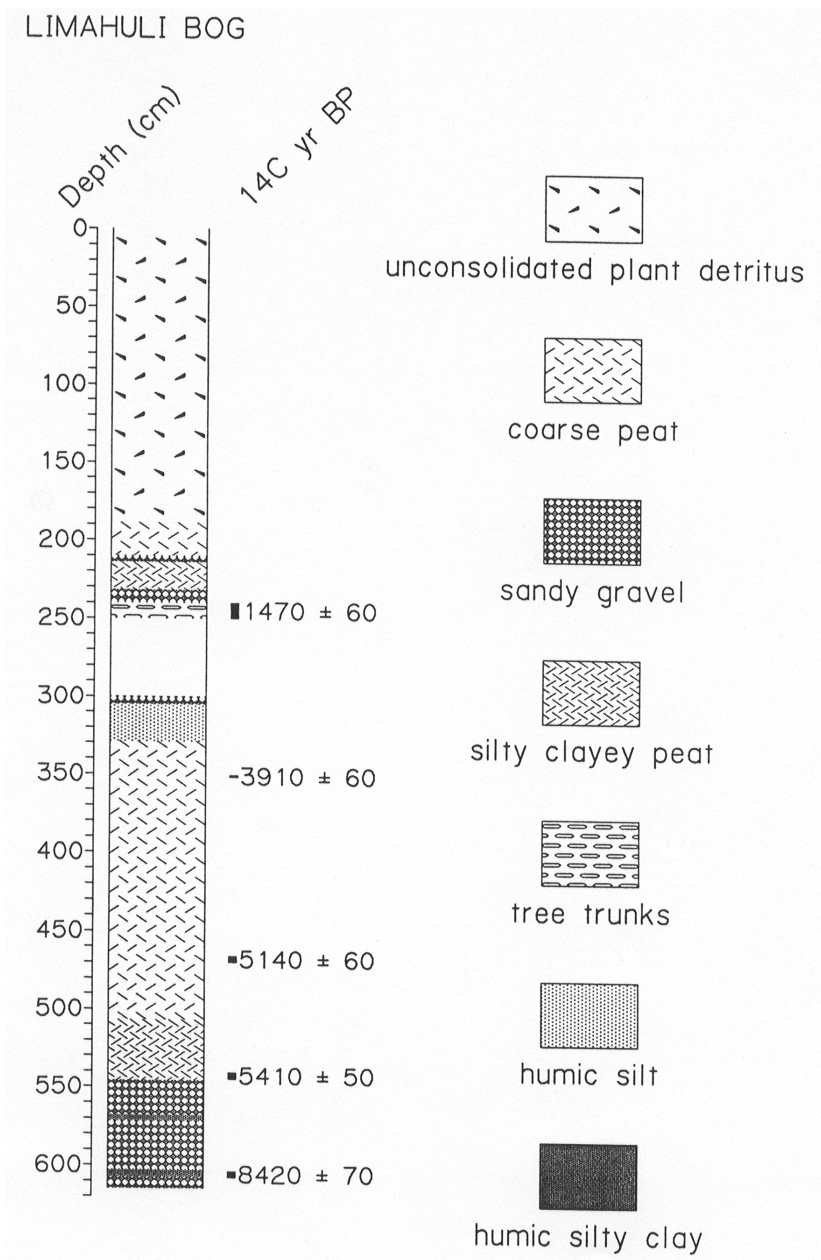

Figure 2 Stratigraphy of a piston core from Limahuli Bog on the north coast

nent flooding of the site, so that peat could begin to accumulate. This would imply that sea level had by $6000 \mathrm{cal} \mathrm{BP}$ risen to within a few meters of present levels, a finding consistent with the advent of ponding and resultant peat accumulation observed from Maha'ulepu Cave on the south coast (Burney et al. 2001). After this time, a generally coarse peat accumulated for several millennia on the site, preserving leaves and stems of grasses, sedges, and ferns.

Between $2.0-3.5 \mathrm{~m}$ in the core, some dramatic changes were occurring. After millennia of peat accumulation, silt, sand, gravel, and wood layers interrupt the sedimentation. Whether these are the result of terrestrial floods or marine events (tsunamis or hurricanes) has not been fully resolved. No marine shells or marine microfossils were noted, but the acidity of the peat layers might have contributed to the dissolution of calcareous materials. However, the pore waters of the sediments appear to have been buffered to approximate neutrality by the alkalinity of calcareous sands. Extreme marine events certainly can not be ruled out, as the large tree trunks at about $2.5 \mathrm{~m}$ depth, overlain by coarse clastics, imply a high-energy event at $1470 \pm 60 \mathrm{BP}(440-670 \mathrm{cal}$ AD). 
The wedge of sand about $50 \mathrm{~cm}$ below the surface along the north edge of the bog is similar to the surficial material derived from the 1946 tsunami, and perhaps represents a similar late prehistoric event such as the one Burney et al. (2001) recorded about 400 BP at Maha'ulepu. The landscape modifications of the Polynesian and European eras are not clearly reflected in increases in clastic sedimentation at the site, unlike the south coast sites studied (see below). This may be a consequence of the heavily vegetated character of this very wet windward site.

\section{Anini Beach and Kealia Beach}

Anini Beach is probably Kaua 'i's most popular location for collecting the prized shells of the large extinct land snails in the genus Carelia, particularly C. cochlea. Avid shell collectors walk the splendid wide beach of the coral-enclosed lagoon to find the auburn $4+\mathrm{cm}$ shells of this terrestrial gastropod. Despite the keen interest in these shells among collectors, there is only one published date, from Ha'ena on the north coast (Dixon et al. 1997). At that site, a sealed deposit of Carelia dolei isenbergi also contained shells of Lamellidea oblonga, a snail believed to have been introduced by prehistoric Polynesians (Cooke and Kondo 1960). The age of the Carelia shell (1390 \pm 60 BP) is possibly coeval with the earliest evidence for human settlement in the Hawaiian Islands (see below). It is widely supposed that humans caused the extinction of many species of this genus, which is known only from Kaua' $\mathrm{i}$ and the neighboring island of Ni'ihau (Cooke 1931; Christensen 1992), perhaps through direct predation, the introduction of rats and chickens, or habitat modification.

A survey of the banks of the small streams that feed the lagoon confirmed our suspicion that eroding terrestrial deposits inshore are the source of the shells that wash up at Anini. The richest in situ deposit we found was about $100 \mathrm{~m}$ inland from the beach road, in a high bank eroded by a small intermittent stream. At this location, Carelia and other shells of extinct land snails are in a matrix of weakly stratified carbonate sands. Excavation of about $0.5 \mathrm{~m}^{3}$ of the fossiliferous layer and overlying sediments was undertaken with $5 \mathrm{~cm}$ vertical control (Figure 3; see Appendix 2 for sediment description). For dating I selected a single $C$. cochlea shell, from $20-25 \mathrm{~cm}$ below datum. It showed no evidence in SEM for recrystallization or exogenous carbonates and retained a significant amount of protein (Ron Hatfield, Beta Analytic, personal communication). AMS determination on the acidetched shell yielded an age of $1840 \pm 50$ BP (70-260, 290-320 cal AD).

Depending on whether one accepts the earliest estimates for human arrival in the Hawaiian Islands, the first century BC (Beggerly 1990) or the first century AD (Hunt and Holsen 1991); or the latest, about $800 \mathrm{AD}$ (Athens 1997); or the approximate median, about $300 \mathrm{AD}$ (Kirch 1985), the dated snail either slightly post-dates, considerably pre-dates, or approximately coincides with the first Polynesians.

Since it is possible that dates on land snail shells may be affected by the intake of calcium carbonate from the substrate, so that they appear older than they actually are (Goodfriend and Hood 1983), this and other land snail dates must be regarded as in effect a maximum age, although the absence of evidence for humans in the levels containing abundant Carelia at Anini cast doubt on the notion that the shells are much younger than their apparent age. In this well-stratified deposit, Carelia becomes scarce above the level of the dated specimen, and no associations with human evidence are apparent. On the surface at the excavation site, and a few $\mathrm{cm}$ below the surface, exotic snails are mixed with human evidence, but Carelia and all but a few of the smaller extinct forms are absent.

It is likely that the deposit of extinct snails, the associated lenses of fine clay, and the humic sand matrix are a paleosol that was rapidly buried by an extreme marine event that deposited the overlying layer containing coralline rubble and broken marine shells. The event inferred from the Limahuli 


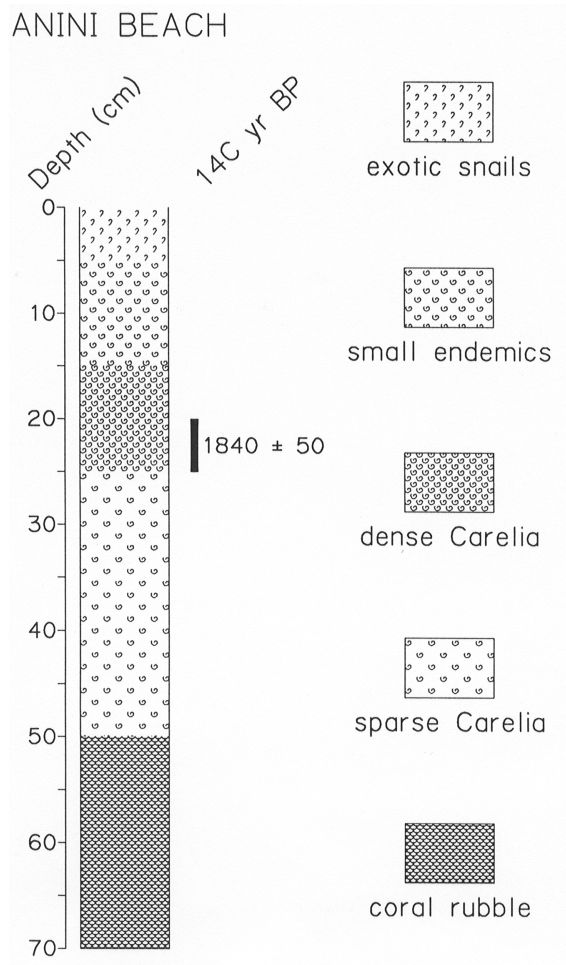

Figure 3 Stratigraphy of excavated snail deposit at Anini Beach on the north coast

Bog sediments (see above) that deposited coarse clastics over tree trunks yielding an age of $1470 \pm$ 60 BP (440-670 cal AD) may be coeval with these overlying deposits at Anini.

Another popular spot with collectors of extinct land snail shells is Kealia Beach on the windward east coast. Although Carelia shells are occasionally found in the dune sands and along the beach at the mouth of the small estuary here, we were unable to find any in situ stratified deposits containing Carelia. Instead, a layer was found in the eroding north bank of the stream that contained some of the medium-sized extinct land snail taxa, including Leptachatina sp. and Amastrella sp., in addition to several smaller genera. This deposit contains evidence for prehistoric humans, in the form of kukui nut shell fragments, marine mollusc shells that are preferred food items of Polynesians, such as opihi (Cellana sp.) and pipipi (Neritina picea) and macroscopic flakes of charcoal.

However, this site is highly disturbed by shell collectors and livestock, so no systematic excavation was undertaken. $\mathrm{A}{ }^{14} \mathrm{C}$ determination was made on an acid-etched shell of the extinct land snail, Leptachatina sp., that SEM analysis showed was only slightly degraded by recrystallization and that still contained some protein (Ron Hatfield, Beta Analytic, personal communication). The date is $1290 \pm 50 \mathrm{BP}(650-870 \mathrm{cal} \mathrm{AD})$, well after many estimates for human arrival and coeval with the latest estimate (Athens 1997).

The pattern observed for Kealia Beach and Anini Beach snails, although hardly a pattern with only two dates, is nevertheless consistent with the recently published evidence from the Maha 'ulepu site snails and supports the hypothesis first proposed there (Burney et al. 2001). We suggested that the 
extinction of land snails on Kaua 'i, and perhaps birds or other taxa as well, followed a three-tiered pattern. Mostly large (Carelia and Cyclamastra) and ornate (Endodonta) taxa seem to disappear first, presumably very soon after human arrival. This event is followed by the later disappearance of mostly medium-sized taxa (e.g. Leptachatina and Amastrella) after several centuries of prehistoric human population increase and resource exploitation. Finally, after European arrival and subsequent ecological changes, a third phase of extinction takes in most of the remaining (generally small) endemic land snails. This pattern is well-demonstrated in the high-resolution stratigraphy at Maha'ulepu, although the lack of data from additional sites (now provided at least scantily by Anini and Kealia) was a limitation.

\section{Alekoko Fishpond and the Huleia Valley}

Alekoko Fishpond and the estuarine deposits of the adjacent Huleia Valley are ideally situated to provide information regarding changes in the lowlands of the SE corner of the island, transitional between windward and leeward. It is also an area of great archaeological and historical interest, as Alekoko is a registered National Historical Landmark and one of the finest examples of prehistoric stonework and fishpond construction in the archipelago.

Alekoko is referred to in many tourist guides as the "Menehune Fishpond," because local legend says the pond was constructed by the menehune, magical beings capable of moving huge stones and doing other large-scale public works literally overnight (Wichman 1998). It has also been suggested that this monumental project was carried out in the 19th century by Chinese plantation labor, although early historical records and photos show that the pond predates the arrival of Chinese laborers (Ching et al. 1973). The accepted view among archaeologists is that this and many other fishponds in the Hawaiian Islands were a product of the advanced aquacultural and wetland agricultural skills of prehistoric Polynesians (Kikuchi 1976).

The pond was formed by walling off a meander on the north side of the Huleia River. This is a pond of the loko kuapa type (Kikuchi 1976). Running for over $600 \mathrm{~m}$, the man-made wall has a dirt base but is faced with fitted stones, some with flattened sides, on the about $200 \mathrm{~m}$ of the wall that spans the deepest water. In more recent times, the wall has been enhanced on the pond side with iron roofing and wooden stakes, and bags of concrete have been stacked as wall stones at some locations (Ching et al. 1973). This repair work probably is the source of the notion that the pond was built by plantation workers.

The pond is about 15.8 ha in area, although siltation and encroachment by introduced mangroves (Rhizophora mangle) and other vegetation has reduced the area of open water in recent years. At low tide the pond is less than $1 \mathrm{~m}$ deep, except for slightly deeper channels immediately inside the two openings in the wall. It is not known for certain whether these were the original locations of makaha or gates, whose subaqueous slats allowed tidal currents and small fish to pass through but prevented the escape of larger fish. A canal (auwai) enters on the SE end of the pond. Tidal flow is unimpeded at the wall openings, with a $<0.5 \mathrm{~m}$ range between normal maximum high and low tides. The pond's water is a variable mixture of salt water from Nawiliwili Bay just downstream, brackish river water, and freshwater inputs from springs and small streams. Salinities measured in the pond throughout the tidal range varied from $20-25 \mathrm{~g} / \mathrm{L}$; water temperature, $22.2-24.4{ }^{\circ} \mathrm{C}$; $\mathrm{pH}, 8.5$; and dissolved oxygen, $7.0 \mathrm{mg} / \mathrm{L}$ (Ching et al. 1973).

Sonar transects were made on the long axis (W-E) at the maximum length of the pond, and on the short axis $(\mathrm{S}-\mathrm{N})$ at the easternmost wall opening. Although the channel through the opening reaches a maximum depth of about $2 \mathrm{~m}$ just inside the pond, no other area of pond bottom was deeper than 
$0.5 \mathrm{~m}$ at low tide on 5 January 1999. A steel probe revealed that soft sediment was at least $2 \mathrm{~m}$ thick over most of the pond bottom, except for a rocky bottom in the vicinity of the wall openings. Water depths just outside the pond wall in the river are generally about $3 \mathrm{~m}$ or less, with rocky and sandy bottom.

A site was selected in the NW quadrant of the pond, in $35 \mathrm{~cm}$ of water (low tide), $30 \mathrm{~m}$ from shore, on a line due $\mathrm{N}$ of the westernmost wall opening. The bottom here is flat and free of roots or evidence of dredging or net-fishing activity. Coring was carried out with a piston-corer from an anchored floating platform constructed from mangrove poles, with two inflatable kayaks and an inflatable raft for flotation. Thin-walled $5 \mathrm{~cm}$ diameter PVC pipe was used for the core barrel. The upper $50 \mathrm{~cm}$ was cored by manual pressure, but the rest of the about $4 \mathrm{~m}$ core required hammering with a sliding drop-hammer rig that advanced the casing about $1 \mathrm{~cm}$ per stroke. Recovery was $>90 \%$ throughout the core, which was recovered in four $1 \mathrm{~m}$ sections (Figure 4; see Appendix 1 for dates and Appendix 2 for core description). Coring was terminated by the indurated nature of the sediments; no rock was encountered.

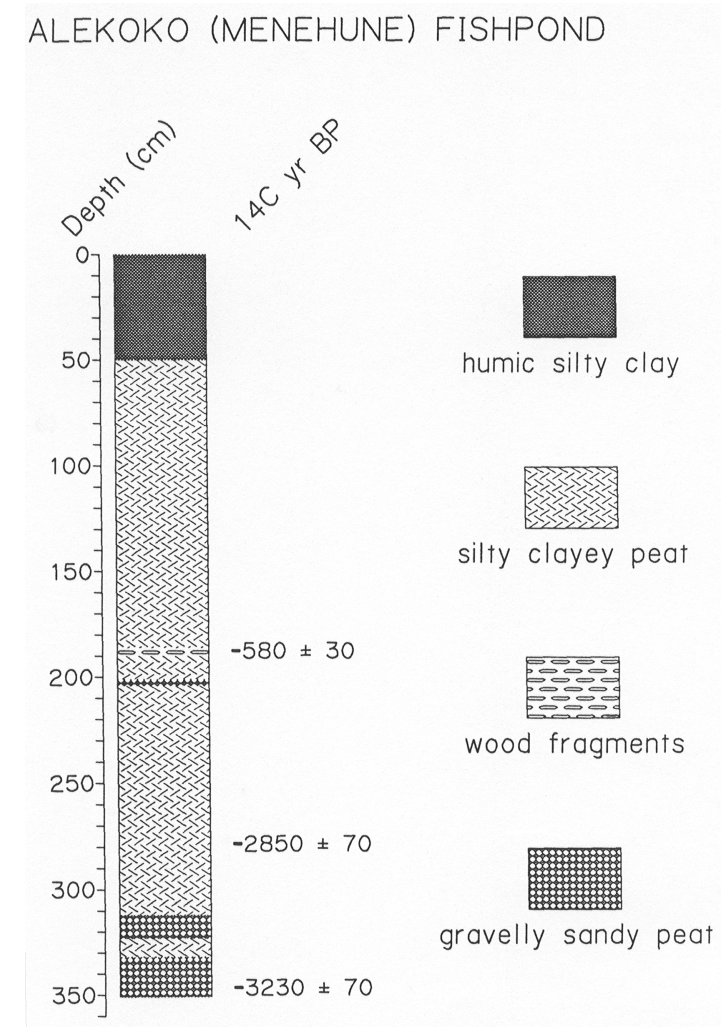

Figure 4 Stratigraphy of a piston core from the Alekoko (Menehune) Fishpond near the southeast coast

In order to assess the sedimentation history of the Huleia Valley outside the pond, six cores were collected from a marshy area $2.4 \mathrm{~km} \mathrm{~W}$ of the pond that has since prehistoric times been utilized intermittently for taro (Colocasia esculenta), as evidenced by the presence of an auwai of the prehistoric Polynesian type, that supplies river water to the fields (W Kikuchi, personal communication), and 
prehistoric walls dividing up the taro pondfields $\left(l o^{\prime} i\right)$. These cores demonstrated a consistent stratigraphic sequence, typified by the piston-core ADA-6 (Figure 5; see Appendix 2 for description).

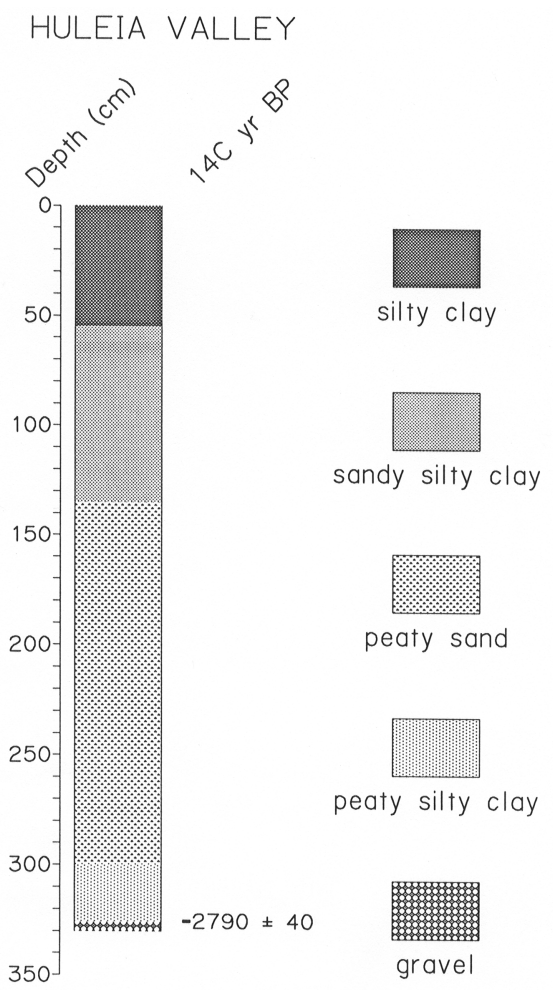

Figure 5 Stratigraphy of piston core ADA-6 from the Huleia Valley upstream from Alekoko Fishpond

It would be premature at this early stage in the ongoing investigations to make firm conclusions regarding the prehistory of Alekoko and the Huleia Valley. A stratigraphy of microscopic charcoal particles from Alekoko is nearly complete, showing a marked increase beginning in the 14th century AD (L P Burney, personal communication). This coincides approximately with a layer of wood detritus described from the Alekoko core that may signal the construction of the pond or an increase in human activity in the vicinity (perhaps the initial deforestation of the adjacent hill slope), dated to $580 \pm 30$ BP $(1305-1420 \mathrm{cal}$ AD). The interpretation that this bend in the river became fully enclosed by a man-made wall at this time is supported by the fact that only fine sediments occur at the level of the wood and above, but the sediments below are punctuated by layers of coarse clastics and large pieces of broken marine mollusc shells. These periodic influxes of coarse material may reflect extreme events such as tsunamis, storm surges, or floods, from which the site was unprotected before the building of the enclosing wall. The general fining-up sequence in the lower part of the Alekoko and Huleia cores, from an earlier unit dominated by coarse clastics to later organicderived sediments, may reflect the effects of sea-level change, as the increasing tidal influence in the lower valley has gradually cancelled out most of the fluvial energy from upstream. 


\section{Maha'ulepu}

Burney et al. (2001) report on four years of field, laboratory, and museum work by a multidisciplinary team of scientists and over 300 volunteers at the extraordinary sinkhole paleolake site in the Maha'ulepu Caves on the leeward south coast. A brief summary is provided here for comparison to the other 11 new sites on Kaua'i.

The eolianite material that comprises the cave and sinkhole walls is derived from dune sands that probably accumulated during a previous high stand of the sea during a Pleistocene interglacial. By about 9500 cal BP a cave had formed that was accumulating sediments on its floor (Figure 6). As sea level rose to within a few meters of its present height, a sea incursion left behind marine bivalves, and parts of the cave roof collapsed, forming a large doline or sinkhole about $7000 \mathrm{cal} \mathrm{BP}$. A lake formed in this sinkhole. The diatom flora in the highly organic sediments indicates that the water was fresh to slightly brackish. Throughout most of the rest of the Holocene, this lake accumulated a rich record of the endemic land snails (at least 14 species), birds (at least 40-43 species), and the macrofossils and pollen of a flora that included a mixture of taxa presently associated with environments from xeric to very wet and a wide range of elevations.
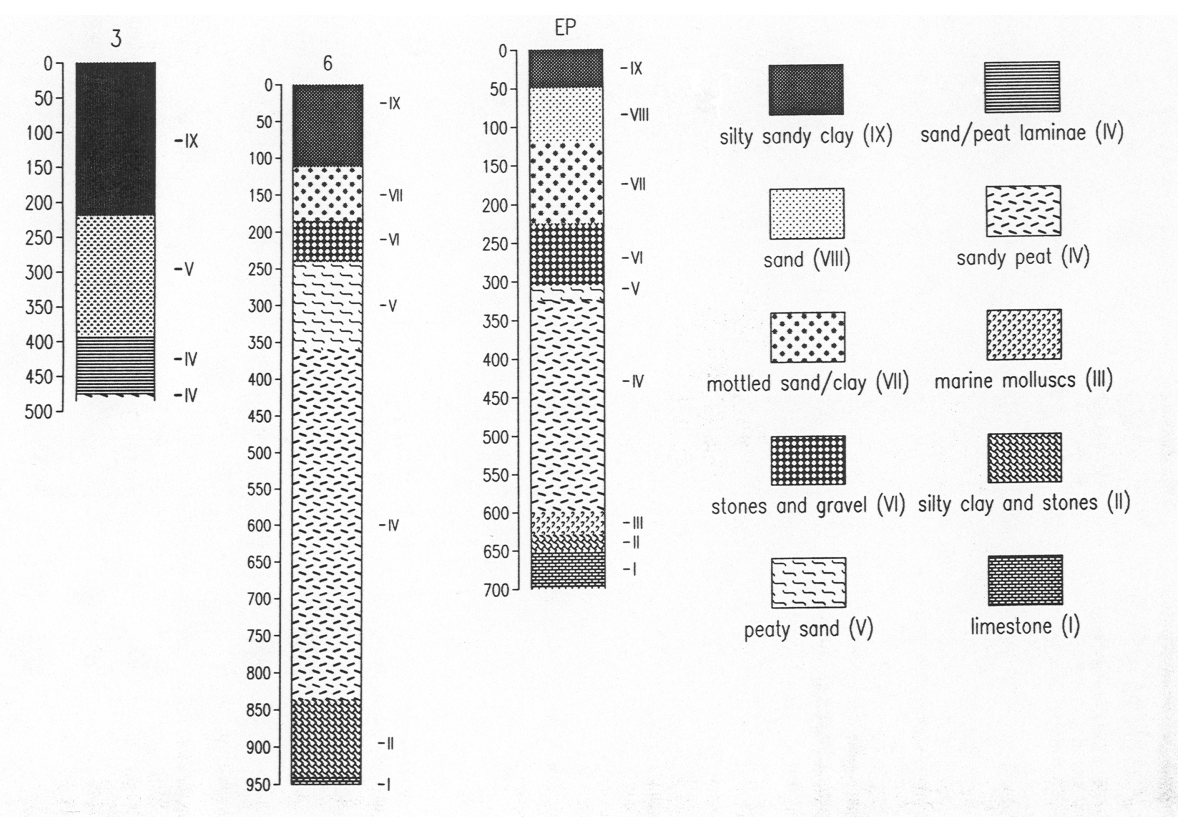

Figure 6 Stratigraphy of two piston cores (BAC-3 and BAC-6) and the EP excavation in the north, center, and east, respectively, of the sinkhole site in the Maha'ulepu Caves on the south coast. Roman numerals indicate stratigraphic units: (I) a previous interglacial; (II) about 9500 cal BP; (III) about 7000 cal BP; (IV) mid- to late-Holocene; (V) late Holocene; (VI) 1430-1665 cal AD; (VII) late 18th century to 19th century; (VIII) 19th to early 20th century; (IX) mid-20th century. See Appendix 1 for dating basis. Adapted from Figures 2 and 3 of Burney et al. (2001).

The first dated evidence for Polynesians at the site, remains of the Pacific rat dated to $822 \pm 60 \mathrm{BP}$ (1039-1241 cal AD), occur in a layer from which some of the endemic snail species, particularly the large Carelia sp. and Cyclamastra cyclostoma, are absent. Many birds now extirpated from Kaua' $\mathrm{i}$ are still represented, for instance, the Laysan Duck (Anas cf. laysanensis) and the Hawaiian Hawk 
(Buteo cf. solitarius), but they and many endemic snail species become scarcer in the layer above, which also contains sedimentary evidence interpreted as a tsunami deposit. During this interval (1430-1665 cal AD) artifactual and midden evidence indicates that prehistoric Polynesians lived nearby. Despite the recovery of extensive dietary remains, including chicken and pig bones, however, no direct evidence was found that these people were utilizing now-extinct birds as food items. The last fossil occurrences of some of these birds occur in this layer. Pollen and macrofossils of many native plant species are still present.

In the late 18th century, thin sand and clay lenses accumulate on the site which contain the first fossils of European-introduced livestock. The remaining native terrestrial snail species decline after European arrival. Many previously well-represented plant species are absent, and others become increasingly scarce. During the 19th century, abundant bones of cows, horses, and other European livestock confirm historical accounts that feral livestock had proliferated along this coast. Photographic evidence suggests that vegetation was suppressed. Pollen data confirm the open and disturbed character of the vegetation at this time, and document the appearance of trees and other plants introduced by Europeans. Dune reactivation resulted in the deposition of a thick sand layer over portions of the site. By the mid-20th century, the drainage of Kapunakea Pond outside the cave, coupled with agricultural development and quarrying activity nearby, led to the highest sedimentation rates recorded at the site. This silty clay documents the appearance of additional introductions, including the Neotropical carnivorous snail Euglandina rosea. The last endemic land snail species, Cookeconcha cf. psaucicostata, disappears concurrent with the arrival of $E$. rosea. Since then, only exotic snails occur in the sediments, alongside other exotic species and the litter of modern life. During Hurricane 'Iniki in September 1992, a storm surge left behind a distinct sedimentary signal of the most severe hurricane event of Kaua 'i's historical period.

This site documents the complete transformation of the biota of Kaua' $i$ (and by analogy, the rest of the Hawaiian Islands as well as many other remote Pacific islands) by human activities, and highlights the strong correlation for a millennium or more between human-assisted biological invasions and disappearance of endemic species. It also documents the drastic range shrinkage of many surviving natives. These include species extirpated on Kaua'i but surviving elsewhere and others highly restricted on Kaua'i today, generally to remote montane environments, that were formerly present even in the dry leeward lowlands. As noted in the previous section on the new results from Anini Beach and Kealia Beach, the pattern of disappearance of endemic land snails at Maha'ulepu seems to conform to three phases that apparently correlate with 1) initial Polynesian colonization, 2) prehistoric population pressures several centuries later, and 3) the accelerated impacts associated with the period after European colonization. The site also provides convincing evidence that a major tsunami struck this location sometime between 1430-1665 cal AD, and that hurricane-driven deposits may have occurred in the sediments intermittently since mid-Holocene times. Comparison of these deposits with those of Hurricane 'Iniki (1992) and the 1946 tsunami suggest that these two types of extreme events can be distinguished from each other and from background sedimentation in the evidence preserved in the sinkhole. The tsunami deposits examined contained much fractured rock and gravel, whereas the hurricane deposits were made up predominantly of wood fragments and sand.

Lawai Kai

Lawai Kai on the south coast $9.1 \mathrm{~km} \mathrm{~W}$ of Maha'ulepu is rather typical of small estuaries in the Hawaiian Islands. The stream's headwaters drain a steep cleft in the basalt highlands, arriving at the coast with clear fast-flowing waters (conductivity $463 \mu \mathrm{mhos} / \mathrm{cm}, \mathrm{pH} 8.5$, temperature $28^{\circ} \mathrm{C}$ ) that 
are tenuously impounded by a longshore sandbar to form a brackish lagoon (conductivity $\leq 34$ mhos $/ \mathrm{cm}$, depending on tide, $\mathrm{pH} 8.0$, temperature $25-29^{\circ} \mathrm{C}$, dissolved $\mathrm{O}_{2}, 7.6 \mathrm{mg} / \mathrm{L}$ ) before emptying into the sea. This area of flat water drains through the beach sand mostly below the surface except on very high tides or during flood conditions. On the $\mathrm{W}$ side of the channel there is a large sediment-filled prehistoric fishpond of the loko kuapa type (Kikuchi 1976) that is impounded by stone walls and packed earth.

Two piston-cores were collected from the estuary, one in the channel about $200 \mathrm{~m}$ inshore from the bar, the other near the center of the sediment-filled prehistoric fishpond. The longer of these, a 654$\mathrm{cm}$ core from the pond (Figure 7) is described in Appendix 2. The channel core is similar, except the top two meters of the profile has been removed by stream erosion. Three bucket-auger soundings were also made to confirm that the pond sediments were fairly uniform over the impounded surface.

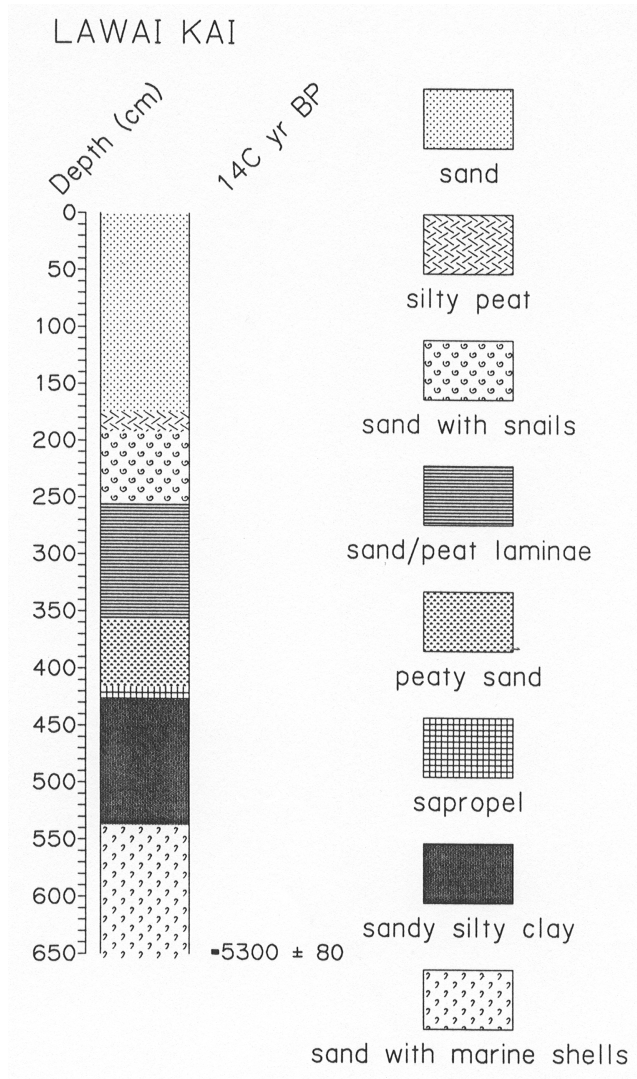

Figure 7 Stratigraphy of the piston core LAK-3 from the prehistoric fishpond/estuary site at Lawai Kai on the south coast

Obviously many more dates are needed for this core to evaluate the impression that the Polynesian and prehuman sequences match very closely the stratigraphy from nearby Maha'ulepu Cave. It would appear that, similar to Maha'ulepu, sea level approached the base level of the site (about $5 \mathrm{~m}$ below present sea level) about $6000 \mathrm{cal} \mathrm{BP}$, depositing marine sediments. This was followed by brackish or freshwater ponding, with periodic coarse-clastic influx, perhaps from storm surges driven by hurricanes. Prior to and during the early Polynesian period, as at Maha'ulepu, endemic 
terrestrial snails were deposited at the site, with a smaller species (Leptachatina cf. fossilis) apparently persisting for some time after a larger species (Cyclamastra cyclostoma) is no longer present in the core.

\section{Kekupua Fishpond}

Kekupua Fishpond is a small shallow body of fresh water on the SW coast of Kaua'i between Makaweli and Waimea. Shaped like an elongate triangle, it measures about $240 \mathrm{~m}$ by $100 \mathrm{~m}$. A causeway of earth and stone separates a small section from the main pond. The pond is shallow (generally $<1 \mathrm{~m}$ ), and most of its surface is covered by sedges, grasses, and the highly invasive water-hyacinth (Eichornia crassipes).

A small ditch drains seaward from the pond. Low dunes separate the pond from the ocean. The waters of Kekupua are fresh to very slightly brackish: at noon on 29 May 1999, the specific conductance was $805 \mu \mathrm{mhos} / \mathrm{cm}$ and five hours later, 830 . The water's $\mathrm{pH}$ is neutral to slightly alkaline, measuring 7.6 and 7.5 at these times. Temperatures and oxygen levels of the surface waters were $23.6{ }^{\circ} \mathrm{C}$ and $24.1{ }^{\circ} \mathrm{C}$, and 8.25 and $8.0 \mathrm{mg} / \mathrm{L}$ at noon and $5 \mathrm{pm}$, respectively.

Only the central portion of the pond has $>1 \mathrm{~m}$ of soft sediment. Probing showed that other areas, including the NE end and accessible points along the NW side, had only $30-100 \mathrm{~cm}$ of soft mud overlying rock. On the SW end, a similarly thin layer of mud overlies sand and gravel.

The thickest deposit of soft sediment found, about $220 \mathrm{~cm}$, was located by probing near the center of the pond, which was covered by about $10 \mathrm{~cm}$ of water at the time of coring. Sediment was recovered in contiguous sections of about $30 \mathrm{~cm}$ each using a $7.5 \mathrm{~cm}$-diameter hand-driven bucket auger (Figure 8; see Appendix 1 for dates and Appendix 2 for description).

It would appear that the site may have been a spring outlet prior to modification by prehistoric Hawaiians. Initially, it experienced a marine overwash episode, perhaps a tsunami, followed by a freshwater swamp-forest (Pandanus) stage. Although Pandanus was much-used by the prehistoric Hawaiians and was until recently believed to have been introduced by them, fossil evidence shows that it is indigenous (Wagner et al. 1999; Burney et al. 2001). In any case, the date on a fruit of this plant $(980 \pm 80 \mathrm{BP})$ does not necessarily provide a date for the construction of the pond, as fishpond management would have probably entailed the removal of Pandanus from the basin although it may well have been growing around the margin. The sediments immediately overlying this fruit, however, are likely to have been deposited subaqueously, and probably provide a reasonable minimum age for the pond construction ( $830 \pm 50 \mathrm{BP} ; 1050-1095,1140-1280 \mathrm{cal}$ AD). The overlying clay layers suggest a subsequent period of erosion, perhaps from prehistoric cultivation of the adjacent banks. Following this erosional phase, the pond has reverted to organic sedimentation, probably reflecting the overgrowth with aquatic vegetation in recent decades. It would appear from the thin mantle of sediments in all areas probed except the pond center that, when the pond was in use for aquaculture and later, for irrigation, some small-scale dredging took place. This notion is supported by oral sources (K McGuire, personal communication).

\section{Inland Sites, Lowest to Highest Elevation}

\section{Silver Falls Ranch}

An extensive bog covers the plateau at the headwaters of Kalihiwai Stream on Kaua 'i's north coast, about $5 \mathrm{~km}$ inland from Anini Beach (see above). Surface flow was not apparent at this site on two dry-season visits, although the water standing at or near the surface in the low interior of the bog 


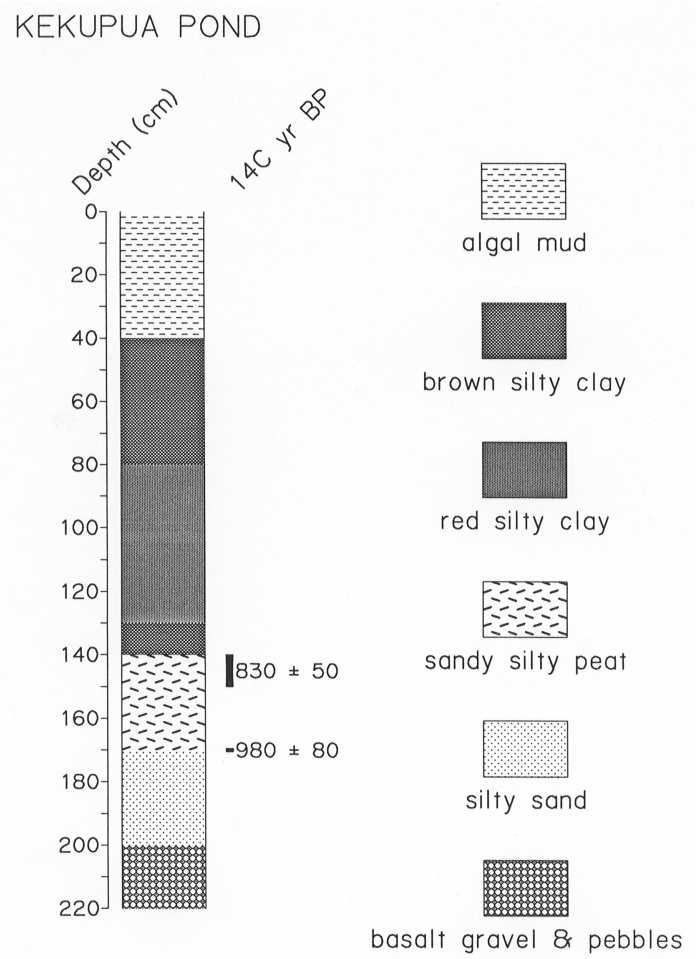

Figure 8 Stratigraphy of the bucket-auger core KEK-3 from Kekupua, a prehistoric fishpond on the south coast

apparently seeps into the stream well above Silver Falls. The bog surface is covered with scattered trees, mostly the invasive exotic Melaleuca quinquenervia but with a few native Metrosideros polymorpha. The understory is made up of a wide variety of grasses and sedges, both native and introduced, and the club-moss Lycopodiella cernua. Insectivorous sundews (Drosera anglica) are extremely common, and, at $169 \mathrm{~m}$ elevation, this is the lowest location at which I have noted this indigenous species on the island.

Two cores, a $2 \mathrm{~m}$ bucket auger core and a piston-core of $3.5 \mathrm{~m}$, were collected in the wettest and most open part of the swamp. These were $1 \mathrm{~m}$ apart, and the stratigraphic description (Figure 9; see Appendix 1 for dates and Appendix 2 for description) employs both of these, as the bucket auger recovered the peaty uppermost layers reasonably intact, but the top $130 \mathrm{~cm}$ was too fibrous for $100 \%$ recovery with the piston corer. The piston-core was utilized for description from this level down to the base of the core at $356 \mathrm{~cm}$, as recovery was virtually $100 \%$ below the uppermost, fibrous levels.

The mottled nature of the humic clays that make up the bulk of this core provides a clue as to why peat formation is not typical here except near the surface. Iron-containing clays and mucks normally gley below the water table to a greenish-gray or bluish-gray color, due to the bacterial reduction of iron under anaerobic conditions. However, periodic drying and cracking of the sediments at the surface because of a fluctuating water table will produce a characteristic mottling through the temporary penetration of oxygen into the otherwise gleyed sediments, resulting in the aeration of exposed sediments and the production of a yellow, orange, or rust-red color where the iron is re-oxidized. This interruption of the normal podzolization may have the added effect of lowering the organic 


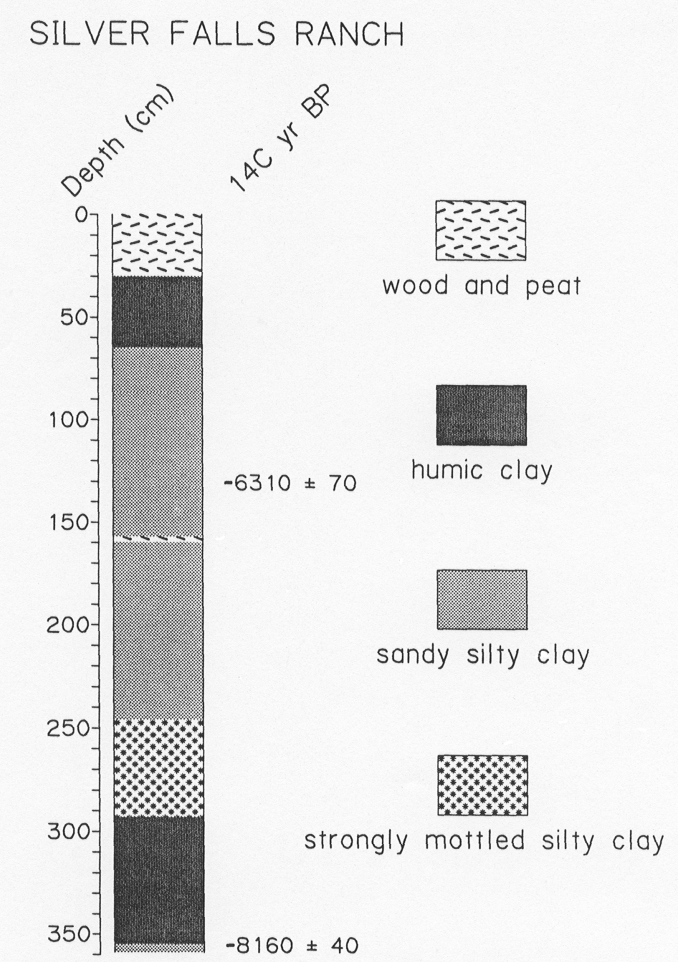

Figure 9 Composite stratigraphy of the bucket auger and piston cores from the bog at Silver Falls Ranch at 169 m elevation on the north side of Kaua $i$

matter content of the sediments, so that only the most refractory components are preserved. In any case, it is clear from the lack of hardpan formation or obvious hiatuses in the core that prolonged periods of desiccation have not occurred here throughout the Holocene. It seems more likely that the fluctuating hydrological conditions that prevail today have been fairly typical for the last 9000 years at this low elevation on the windward side of the island.

\section{Kilohana Crater}

Kilohana Crater is one of the more striking landscape features on Kaua' $i$. Whereas the original volcanism that formed the island occurred millions of years ago, with subsequent erosion erasing most primary volcanic features, the much later rejuvenation stage has left behind a series of Pleistocene craters (of which Kilohana is the largest) along faults running roughly north to south along the eastern side (MacDonald et al. 1983). The large oval crater, $1.1 \times 0.8 \mathrm{~km}$, has a swamp forest of exotic trees on its mostly flat base (elevation $243 \mathrm{~m}$ ), growing in a heavy clay base that stays moist throughout the year.

This clay proved too hard and viscous for piston-coring, but a bucket auger core was taken in the hope of reaching softer sediments beneath. The resulting stratigraphy (Figure 10; see Appendix 2 for sediment description) provides a record of late Pleistocene conditions at this inland site on the SE side of the island, transitional between windward and leeward. 


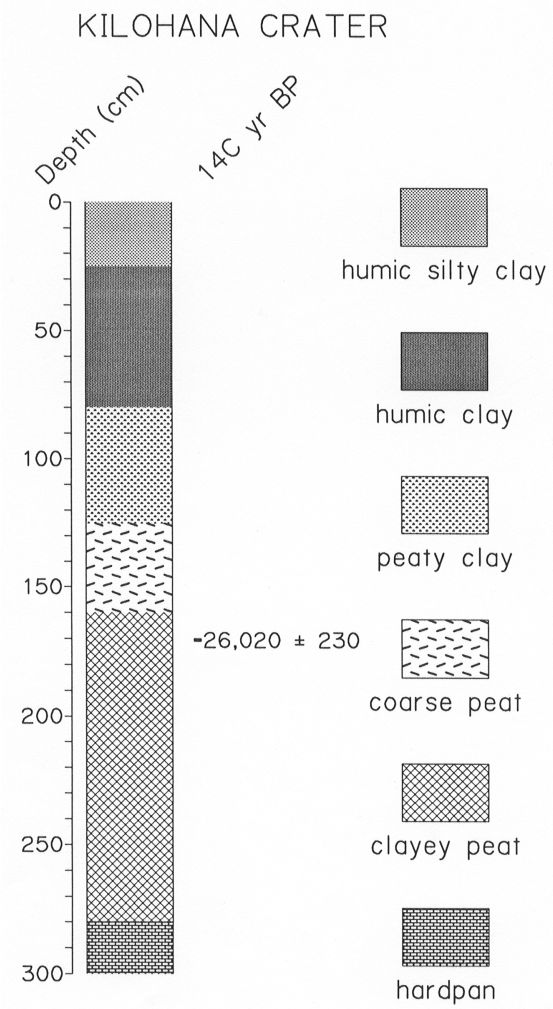

Figure 10 Stratigraphy of a bucket auger core from the floor of Kilohana Crater at $243 \mathrm{~m}$ elevation in the southeastern part of Kaua' $\mathrm{i}$

Although there is a need for an additional date from the top of the organic sequence at $80 \mathrm{~cm}$, it is tempting to speculate that the pattern at this site is for wetter conditions in the late Pleistocene, prior to glacial maximum, followed by drier conditions ever since, including the entire Holocene. However, caution is in order, as the small stream that breaches the crater on the west side may have simply downcut the barrier formed by the lowest place on the crater rim, lowering the water level in the bog or shallow pond that existed here 26,000 years ago.

\section{Wahiawa Bog}

Wahiawa Bog is a large remote montane bog at $665 \mathrm{~m}$ elevation in the south central interior of the island. The bog is one of the lowest locations on the island in which the vegetation is still essentially native, with many rare endemics. Perched on a high, flat interfluve, the bog is drained by first-order streamlets around its edges, with the water table just below the mossy surface during relatively dry weather.

Although a $4.9 \mathrm{~m}$ piston core has been obtained from the approximate center of the bog (Figure 11; see Appendix 1 for dates and Appendix 2 for sediment description), probing indicates that longer cores are feasible. Recovery was essentially $100 \%$ for all sections of the core except one very hard, dry unit. 


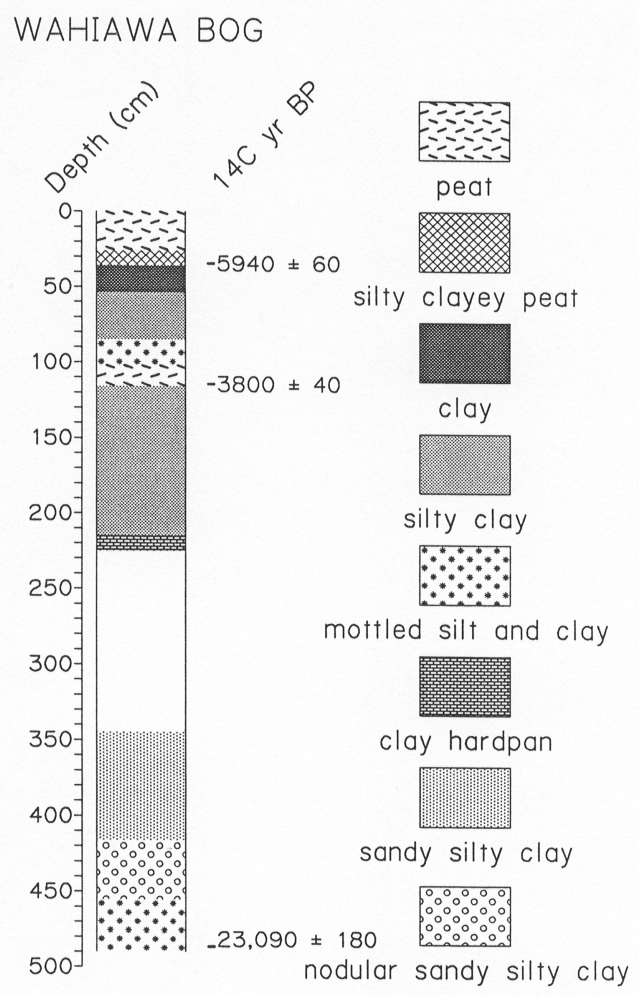

Figure 11 Stratigraphy of a piston core from Wahiawa Bog at $665 \mathrm{~m}$ elevation in the southern interior

It is not clear why the two Holocene dates near the top of the core are stratigraphically reversed. The most parsimonious explanation would be that the lower, younger date was somehow contaminated by younger material from above. In any case, it is safe to say that the upper part of the core is Holocene, and the lowermost part, below the very problematic hardpan, is late Pleistocene. The apparent absence of late Holocene sedimentation at the site is similar to the conditions described by Hotchkiss (1998) at Ka'au Crater on Oahu, where sediments from a depth of 50-60 cm dated to $7330 \pm 100$ BP. Apparently some mid-elevation bogs in the Hawaiian Islands have accumulated peat only very slowly if at all in recent millennia.

\section{Kilohana (Alakai Swamp)}

The Kilohana area of the vast Alakai Swamp of NW Kaua'i has several open grass-sedge bogs with patches of standing water. The Kilohana bogs (not to be confused with Kilohana Crater in SE Kaua ' $i$, see above) first attained notice in the scientific literature as a coring site of Selling (1948) who obtained cores up to $275 \mathrm{~cm}$ in length with a peat borer and produced elaborate pollen diagrams showing interesting vegetation changes (undated, ${ }^{14} \mathrm{C}$ dating would not come into general use until several years later). After careful study of his published notes on the site, we attempted with the modern advantages of good topographic maps and a Global Positioning System unit to relocate and re-core his Kilohana site so that it would be possible to date the key sediment horizons he identified in his landmark study. 
Throughout the vicinity, we systematically probed the soft peat layers with a thin steel rod to find a site with a relatively thick deposit, free of large roots. At the site selected, isolated from woody vegetation about $100 \mathrm{~m} \mathrm{~S}$ of the boardwalk trail, and $50 \mathrm{~m}$ on a bearing of $285^{\circ}$ from the gate located near the SW corner of the exclosure fence, we obtained a piston core of $3.2 \mathrm{~m}$ (Figure 12; see Appendix 1 for dates and Appendix 2 for sediment description). The top $10 \mathrm{~cm}$ of the profile, a mixture of fine roots and peat, was removed intact with a spade and subsampled. A steel tripod was erected over this hole, for attachment of a piston cable. The peat unit was easily extracted by hand operation, with $100 \%$ recovery. With the aid of a drop-hammer system below the peat, coring revealed stiff clay and gravel layers. Recovery of the units below the peat was about $70 \%$, owing to the viscosity of the clays and the presence of rocks in lower layers.

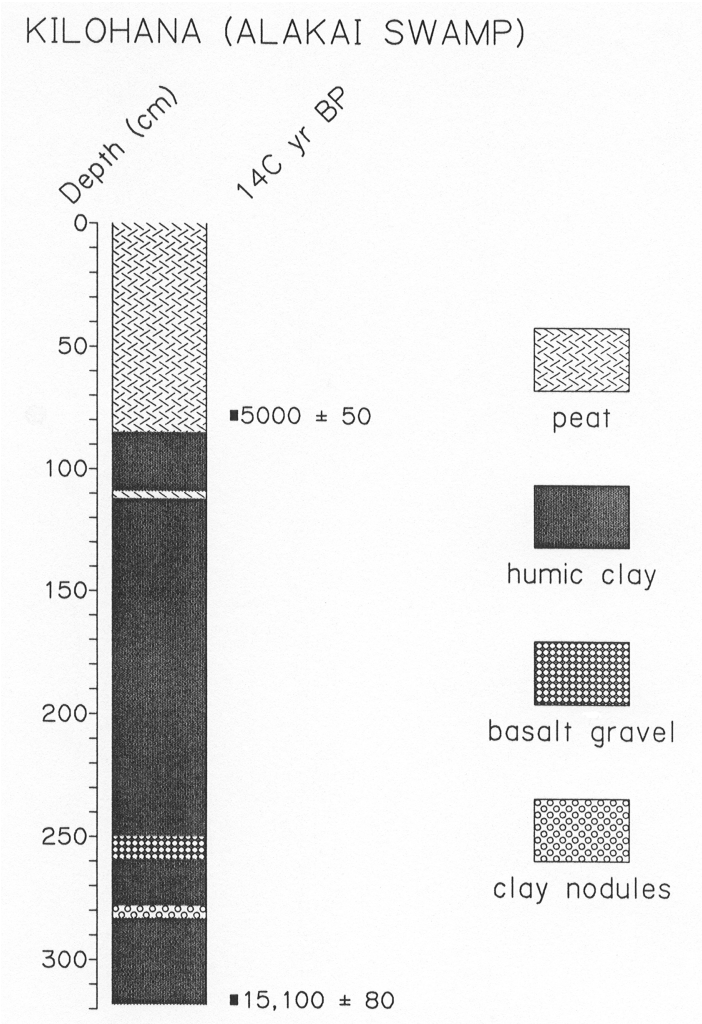

Figure 12 Stratigraphy of a piston core from the Kilohana area of Alakai Swamp at $1220 \mathrm{~m}$ in the NW highlands

The late Holocene bog on this site is probably of the ombrotrophic type, in which few nutrients or inorganic minerals reach the site except as airborne dust or nucleating bodies of raindrops. The clastic-starved nature of these sediments is apparent from the peat itself, which is virtually devoid of allochthonous materials larger than about $10 \mu$. The shortage of available cations is also apparent from the chemistry of the water in a small pond adjacent to the coring site. This remarkably dilute and extremely acid water probably reflects the chemistry of the near-surface sediment pore-water, with a specific conductance of $43.8 \mu \mathrm{mhos} / \mathrm{cm}$ and $\mathrm{pH}$ of 4.2 . 
The peat unit begins accumulating just below the level dated to $5000 \pm 50 \mathrm{BP}$. It is possible that wetter conditions ensued at high elevations in the Hawaiian Islands about this time, as observed in a core from a bog on Maui about $1000 \mathrm{~m}$ higher in elevation (Burney et al. 1995). The peat is extremely pollen-rich, and forthcoming analysis will be useful for comparison to Selling's undated stratigraphy. Pollen is also rich in the transition to clay, and continues with lower concentration and poorer preservation intermittently through the underlying clay. Sufficient plant fiber and other insoluble organic matter persists in the basal clay for ${ }^{14} \mathrm{C}$ dating. Since stratigraphic leakage of insoluble organic particles through $2 \mathrm{~m}$ of dense fine clay is improbable, this must be in situ organic matter and not particles somehow transported from the overlying peat (which in any case dates to 10,000 yr younger). These observations would suggest that the clay is not purely a subsurface weathering product from the underlying basalt, nor a leached layer derived from the overlying peat. Instead, some clay deposition must have occurred on the paleosurface, before the peat accumulated, perhaps under a drier or more seasonal climatic regime. Similar modern deposition was observed nearby along the more well-drained and more eroded margin of the bog surface, where some clay appears to be weathering out of protruding rocks, mixing with recent organic materials, and collecting in wet hollows nearby.

The thin layer of peat described from the upper part of the clay at $110 \mathrm{~cm}$ bears further investigation. It may indicate a brief wetter interval in the early Holocene or a shift in the pattern of local drainage. The preservation of this thin structure indicates a lack of bioturbation and stratigraphic leakage in the upper clay member and provides further evidence that the clay units are depositional, and not formed in situ.

A drier climate or small-scale geomorphological events may explain the presence of the layer of weathered basalt deep in the clay, and the hardened clay nodules even deeper. These layers may represent deflation or sheet erosion of the clay surface during a dry interval, producing a lag concentrate of large refractory particles on the paleosurface. An alternate explanation, that basalt was deposited here in postglacial times from late volcanic activity on the island, seems improbable in the light of the reconstructed volcanic history of Kaua' $i$. This relatively old island is thought to have been volcanically quiescent since the late Pleistocene (MacDonald et al. 1983). It is far more likely that the clays and gravels here were deposited in a somewhat different kind of environment from the peat bog that has existed in the Alakai at least since the mid-Holocene. Under drier conditions than today, such flat terrain might be expected to accumulate humic silty clays, gravel, and clay nodules as periodic sheet-flow, and subsequent deflation and erosion may have reworked clastics while oxidation removed all but the most refractory organic matter. If these clays are at least partly depositional, as suggested by the sedimentology and dating, it is also possible that a longer record could be obtained here. With appropriate coring equipment, it might be feasible to penetrate these postglacial clays to deeper layers of peat that may have accumulated during wetter intervals of the late Pleistocene. Based on the local geomorphology, there is no reason to believe that the Alakai Swamp is only 15,000 years old.

\section{Landscape-Level Integration}

Although reconstructions for most of the sites presented here must remain tentative pending additional dating and microfossil studies, it is possible to integrate some of the information concerning sedimentation at the landscape level.

1) At inland sites, some organic deposition occurred in the late Pleistocene prior to the last glacial maximum, but these sites were relatively dry after this time until the mid-Holocene. Peat has accumulated on inland bog sites since the mid-Holocene but at a very slow rate, generally about $0.1 \mathrm{~mm} / \mathrm{yr}$. 
2) Along both windward and leeward coasts, organic sedimentation begins in the presently existing estuaries about 6000 BP. These sites accumulated mid- and late Holocene sediments at a moderate rate, generally about $1-2 \mathrm{~mm} / \mathrm{yr}$, but gradual organic sedimentation has been periodically overlain by coarse clastics from extreme events including tsunamis, hurricanes, and floods.

Results from these sites do not resolve the long-standing controversy regarding the possibility of a mid-Holocene high stand in the Hawaiian Islands, possibly to $1.8 \mathrm{~m}$ ASL (Stearns 1978; Jones 1992). It is surprising that the coastal sites generally show evidence for fresh or brackish water ponding in the mid-Holocene, rather than marine sedimentation. Detailed studies of estuarine geomorphology could help clarify the extent to which mid-Holocene aggradation of shorelines and possibly extensive progradation since that time (as sea level dropped to approximately present levels) might explain the observed estuarine stratigraphy. Otherwise, the evidence presented here is consistent with a pattern of rapid postglacial rise to a few meters below present sea level by $6000 \mathrm{BP}$, followed by gradual rise since that time.

3) Evidence accumulated thus far supports the later estimates for human colonization. The Pacific rat was established by the beginning of the last millennium, shortly after $1000 \mathrm{AD}$. Large land snails disappear from some sites by this time or before. Other snails decline during prehistoric Polynesian times but disappear before European contact. Most of the remaining endemic land snails have been extirpated in the last two centuries following European arrival.

4) Prehistoric fishpond construction was initiated by $830 \pm 50$ BP $(1050-1095,1140-1280 \mathrm{cal}$ AD) with one of the largest such structures probably completed by $580 \pm 30 \mathrm{BP}(1305-1420 \mathrm{cal}$ AD). Thus, although detection of earliest evidence for human activity remains an elusive goal, it is likely that large human populations had been attained on the island by the time fishpond construction was initiated, since this form of intensive aquaculture would hardly have been justifiable before food resources became relatively scarce, manual labor abundant, and highly structured chiefdoms established.

5) At some drier sites on the leeward south coast, sedimentation rates may have increased after human arrival and greatly accelerated in European times (certainly more than two orders of magnitude at Maha'ulepu, with similar rates likely at Alekoko, Huleia Valley, Lawai Kai, and Kekupua). No anthropogenic acceleration was detected in wetter sites both on the windward north coast and in interior bogs, probably owing to the more heavily-vegetated character of the former and the isolation from most human activity of the latter.

Much remains to be done on these sites, including additional sampling and dating, microfossil analyses, vertebrate studies, and site integration. The ${ }^{14} \mathrm{C}$ dated stratigraphies presented here confirm that the island and the methodologies employed have good potential for drawing landscape-level inferences regarding late Quaternary (near time) events on the isolated landmasses of the mid-Pacific.

\section{ACKNOWLEDGMENTS}

Thanks to over 300 people who have assisted with coring and excavation throughout Kaua 'i. Many muddy hours were contributed to coring efforts in particular by Adam Asquith, Alec Burney, Lida Pigott Burney, Reginald Gage II, Don Heacock, Helen James, Pila and Dolly Kikuchi, Kristina Kikuchi-Palenapa, Lorrin Mano'i, Ka'ohulani McGuire, Cameron McNeil, Bob Nishek, Storrs Olson, Mary L O'Rourke, and Ed Sills. Thanks also to the landowners, public and private, who permitted us to work on their property. Nancy McMahon assisted with official permissions. Lida Pigott 
Burney provided useful comments on the manuscript and assisted with all phases of the laboratory work. Paul S Martin reviewed the manuscript and made helpful suggestions. This research was supported by NOAA Human Dimensions of Global Change grant \#NA46GP0465, NSF grant DEB9707260, National Geographic Society grant 7072-01, and funding from the Smithsonian Institution, Kaua'i Community College, Kilauea Point Natural History Association, and the Faculty Research Grants and Faculty Fellowship programs of Fordham University.

\section{REFERENCES}

Armstrong RW, editor. 1983. Atlas of Hawaii. Second edition.

Athens JS. 1997. Hawaiian native lowland vegetation in prehistory. In: Kirch PV, Hunt TL, editors. Historical ecology in the Pacific Islands. New Haven, Connecticut: Yale University Press. p 248-70.

Beggerly PEP. 1990. Kahana Valley, Hawaii, a geomorphic artifact. Ph.D. thesis. University of Hawaii. Honolulu.

Burney DA, DeCandido RV, Burney LP, Kostel-Hughes FN, Stafford TW, Jr., James HF. 1995. A Holocene record of climate change, fire ecology, and human activity from montane Flat Top Bog, Maui. Journal of Paleolimnology 13:209-17.

Ching FKW, Griffin PB, Kikuchi WK, Albrecht WA, Belshé JC, Stauder C. 1973. The archaeology of Puna, Kaua'i. Archaeological Research Center Hawaii. $123 \mathrm{p}$.

Christensen C. 1992. Kauai's native land shells. Honolulu: Fisher.

Cooke CM. 1931. The land snail genus Carelia. Bishop Museum Bulletin 85. Honolulu: Bishop Museum Press.

Cooke CM, Kondo Y. 1960. Revision of Tornatellinidae and Achatinellidae (Gastropoda, Pulmonata). Bishop Museum Bulletin 221. Honolulu: Bishop Museum Press.

Dixon B, Soldo D, Christensen CC. 1997. Radiocarbon dating land snails and Polynesian land use on the island of Kaua 'i, Hawai 'i. Hawaiian Archaeology 6:5262.

Gavenda RT. 1992. Hawaiian Quaternary paleoenvironments: a review of geological, pedological, and botanical evidence. Pacific Science 46:295-307.

Goodfriend G, Hood D. 1983. Carbon isotope analysis of land snail shells: implications for carbon sources and radiocarbon dating. Radiocarbon 25(2B):810-30.

Hearty PJ, Kaufman DS, Olson SL, James HF. 2000. Stratigraphy and whole-rock amino acid geochronology of key Holocene and last interglacial carbonate deposits in the Hawaiian Islands. Pacific Science 54: 423-42.

Hotchkiss SC. 1998. Quaternary vegetation and climate of Hawai' $i$. PhD thesis. University of Minnesota.

Hunt TL, Holsen RM. 1991. An early radiocarbon chronology for the Hawaiian Islands: a preliminary analysis. Asian Perspectives 30:147-61.

James HF, Olson SL. 1991. Descriptions of thirty-two new species of birds from the Hawaiian Islands: Part II. Passeriformes. Ornithological Monographs 46. Washington D.C.: American Ornithologists' Union.

Jones AT. 1992. Holocene coral reef on Kaua 'i, Hawai 'i: evidence for a sea-level high-stand in the central Pacific. In: Fletcher III CH, Wehmiller JF, editors. Quaternary coasts of the United States: marine and lacustrine systems. SEPM Special Publication 48:267-71. Tulsa, Oklahoma: Society for Sedimentary Geology.

Kikuchi WK. 1976. Prehistoric Hawaiian fishponds. Science 193:295-9.

Kirch PV. 1985. Feathered gods and fishhooks. Honolulu: University of Hawaii Press.

MacDonald GA, Abbott AT, Peterson FL. 1983. Volcanoes in the sea: the geology of Hawaii. Honolulu: University of Hawaii Press.

Olson SL, James HF. 1982. Prodromus of the fossil avifauna of the Hawaiian Islands. Smithsonian Contributions to Zoology 365. Washington D.C.: Smithsonian Institution Press.

Olson SL, James HF. 1991. Descriptions of thirty-two new species of birds from the Hawaiian Islands: Part I. Non-Passeriformes. Ornithological Monographs 46. Washington D.C.: American Ornithologists' Union.

Olson SL, James HF. 1997. Prehistoric status and distribution of the Hawaiian Hawk (Buteo solitarius), with the first fossil record from Kaua'i. Bishop Museum Occasional Papers 49:65-9.

Selling O. 1948. Studies in Hawaiian pollen statistics: Part III. On the Late Quaternary history of the Hawaiian vegetation. Bernice P. Bishop Museum Special Publication 39. Honolulu.

Stearns HT. 1978. Quaternary shorelines in the Hawaiian Islands. Bernice P. Bishop Museum Bulletin 237. Honolulu.

Stuiver M, Braziunas TF. 1993. Modeling atmospheric ${ }^{14} \mathrm{C}$ ages of marine samples to 10,000 BC. Radiocarbon 35:137-89.

Stuiver M, Reimer PJ, Bard E, Beck JW, Burr GS, Hughen KA, Kromer B, McCormac FG, van der Plicht J, Spurk M. 1998. INTCAL98. Radiocarbon 40(3): 1041-83.

Wagner WL, Herbst DR, Sohmer SH. 1999. Manual of the flowering plants of Hawaii. Bishop Museum Special Publication 97. Honolulu.

Wichman FB. 1998. Kaua' $i$ : ancient place-names and their stories. Honolulu: University of Hawaii Press. 
${ }^{14} \mathrm{C}$ dating and calibrations for new sites on Kaua' $\mathrm{i}$

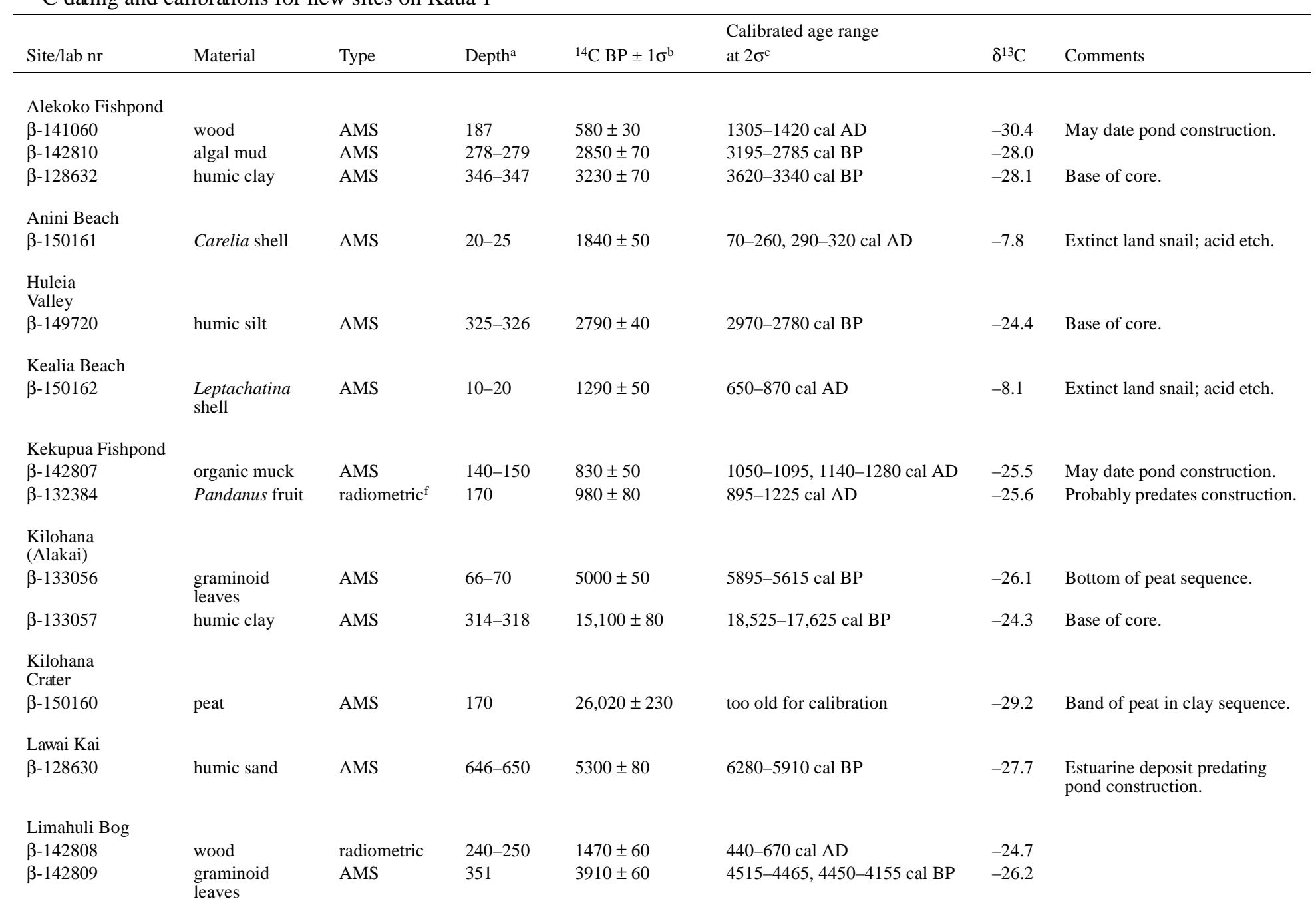


${ }^{14} \mathrm{C}$ dating and calibrations for new sites on Kaua'i (Continued)

\begin{tabular}{|c|c|c|c|c|c|c|c|}
\hline Site/lab nr & Material & Type & Depth $^{\mathrm{a}}$ & ${ }^{14} \mathrm{C}$ yr BP $\pm 1 \sigma^{\mathrm{b}}$ & $\begin{array}{l}\text { Calibrated age range } \\
\text { at } 2 \sigma^{c}\end{array}$ & $\delta^{13} \mathrm{C}$ & Comments \\
\hline$\beta-128631$ & $\begin{array}{l}\text { graminoid } \\
\text { leaves }\end{array}$ & AMS & $466-470$ & $5140 \pm 60$ & $5995-5740 \mathrm{cal} \mathrm{BP}$ & -24.1 & \\
\hline$\beta-133058$ & wood & AMS & $541-545$ & $5410 \pm 50$ & $6295-6105,6070-6020 \mathrm{cal}$ BP & -25.2 & Bottom of peat sequence. \\
\hline$\beta-133059$ & humic silt & AMS & $604-608$ & $8420 \pm 70$ & $9535-9280 \mathrm{cal} \mathrm{BP}$ & -26.2 & Near base of core. \\
\hline \multicolumn{8}{|c|}{ Maha‘ulepu Caves } \\
\hline$\beta-134126$ & Aleurites seed & radiometric & $265-275$ & $230 \pm 70$ & $1490-1890,1910-1950 \mathrm{cal}$ AD & -25.1 & S50, Middle Pit excavation. \\
\hline$\beta-134127$ & Aleurites seed & radiometric & $275-285$ & $190 \pm 60$ & $1530-1545,1635-1955 \mathrm{cal}$ AD & -23.7 & S50, Middle Pit excavation. \\
\hline$\beta-149721$ & Cordia fruit & AMS & 530 & $4610 \pm 60$ & $5470-5620,5180-5060 \mathrm{cal} \mathrm{BP}$ & -27.2 & Core 20. \\
\hline$\beta-151833$ & humic sand & AMS & $469-473$ & $3800 \pm 40$ & $4290-4080$ cal BP & -8.4 & Core 6. \\
\hline$\beta-110270$ & Aleurites seed & AMS & $142-146$ & $10 \pm 40$ & too recent for calibration & -25.4 & N35, South Cave excavation. ${ }^{\mathrm{h}}$ \\
\hline$\beta-67394$ & humic silty clay & AMS & $112-113$ & $2145 \pm 55^{\mathrm{d}}$ & not applicable (date rejected) & -26.4 & Core $3 .^{\mathrm{h}}$ \\
\hline$\beta-122587$ & Aleurites seed & radiometric & $275-285$ & modern & too recent for calibration & -22.6 & J34, South Cave excavation. ${ }^{\mathrm{h}}$ \\
\hline$\beta-122586$ & Aleurites seed & radiometric & $305-315$ & $20 \pm 60$ & $\begin{array}{l}\text { AD 1685-1735, 1810-1925, } \\
1950-1955+\end{array}$ & -24.3 & J34, South Cave excavation. ${ }^{\mathrm{h}}$ \\
\hline$\beta-122588$ & Aleurites seed & radiometric & $245-255$ & $100 \pm 50$ & AD 1665-1955 & -25.8 & J34, South Cave excavation. ${ }^{\mathrm{h}}$ \\
\hline$\beta-116527$ & Aleurites seed & radiometric & $155-160$ & $160 \pm 60$ & AD 1645-1955 & -21.9 & O33, South Cave excavation. ${ }^{\mathrm{h}}$ \\
\hline$\beta-116526$ & Aleurites seed & radiometric & $150-155$ & $220 \pm 60$ & $\begin{array}{l}\text { AD 1515-1590, 1620-1885, } \\
1910-1950\end{array}$ & -24.5 & N33, South Cave excavation. ${ }^{h}$ \\
\hline$\beta-122585$ & Lagenaria rind & AMS & $325-335$ & $180 \pm 50$ & AD $1645-1950$ & -28.2 & J34, South Cave excavation. ${ }^{\mathrm{h}}$ \\
\hline$\beta-110271$ & Aleurites seed & AMS & $225-235$ & $90 \pm 40$ & $\begin{array}{l}\text { AD 1675-1765, 1800-1940, } \\
1945-1955\end{array}$ & -24.5 & LL49, East Pit excavation. ${ }^{\text {h }}$ \\
\hline$\beta-110272$ & Aleurites seed & AMS & $245-255$ & $340 \pm 40$ & AD $1450-1650$ & -25.4 & LL49, East Pit excavation. ${ }^{\text {h }}$ \\
\hline$\beta-110273$ & Aleurites seed & AMS & $275-285$ & $300 \pm 40$ & AD $1480-1660$ & -25.4 & LL49, East Pit excavation. ${ }^{\mathrm{h}}$ \\
\hline$\beta-116189$ & Aleurites seed & AMS & $235-245$ & $380 \pm 50$ & AD 1430-1645 & -24.1 & KK47, East Pit excavation. ${ }^{\mathrm{h}}$ \\
\hline$\beta-115789$ & Lagenaria rind & AMS & $285-295$ & $410 \pm 40$ & AD $1425-1520,1575-1625$ & -25.9 & JJ46, East Pit excavation. ${ }^{\mathrm{h}}$ \\
\hline NZA 10058 & $\begin{array}{l}\text { bone }(R . \text { exu- } \\
\text { lans) }\end{array}$ & AMS & $305-315$ & $822 \pm 60^{e}$ & AD 1039-1241 & -13.2 & LL49, East Pit excavation. ${ }^{\mathrm{h}}$ \\
\hline NZA 10056 & $\begin{array}{l}\text { bone (Grallis- } \\
\text { trix) }\end{array}$ & AMS & $245-255$ & $2328 \pm 60$ & $\begin{array}{l}2485-2299,2265-2178,2168- \\
2157 \mathrm{cal} \mathrm{BP}\end{array}$ & -16.0 & KK46, East Pit excavation. ${ }^{\mathrm{h}}$ \\
\hline$\beta-67395$ & $\begin{array}{l}\text { humic sandy } \\
\text { clay }\end{array}$ & AMS & $296-297$ & $2705 \pm 55$ & $2910-2745$ cal BP & -24.4 & Core $3 .^{h}$ \\
\hline NZA 10057 & bone (Buteo) & AMS & $245-255$ & $3416 \pm 60$ & 3830-3475 cal BP & -15.9 & KK46, East Pit excavation. ${ }^{\text {h }}$ \\
\hline$\beta-128626$ & sandy peat & AMS & $356-358$ & $3760 \pm 70$ & 4380-3915 cal BP & -20.2 & Core $6{ }^{\mathrm{h}}$ \\
\hline$\beta-110275$ & sandy peat & radiometric & $305-315$ & $3670 \pm 60$ & $4155-3845 \mathrm{cal} \mathrm{BP}$ & -25.8 & LL49, East Pit excavation. ${ }^{\mathrm{h}}$ \\
\hline$\beta-110274$ & sandy peat & radiometric & $365-375$ & $4310 \pm 60$ & $5035-5005,4990-4820$ cal BP & -24.3 & LL49, East Pit excavation. ${ }^{\mathrm{h}}$ \\
\hline$\beta-115788$ & Cordia fruit & AMS & $265-275$ & $4680 \pm 50$ & $5580-5515,5490-5305$ cal BP & -23.8 & KK46, East Pit excavation. ${ }^{\mathrm{h}}$ \\
\hline
\end{tabular}


${ }^{14} \mathrm{C}$ dating and calibrations for new sites on Kaua'i (Continued)

\begin{tabular}{|c|c|c|c|c|c|c|c|}
\hline Site/lab nr & Material & Type & Depth $^{\mathrm{a}}$ & ${ }^{14} \mathrm{C}$ yr BP $\pm 1 \sigma^{b}$ & $\begin{array}{l}\text { Calibrated age range } \\
\text { at } 2 \sigma^{c}\end{array}$ & $\delta^{13} \mathrm{C}$ & Comments \\
\hline$\beta-115790$ & Cordia fruit & AMS & $305-315$ & $4960 \pm 50$ & $5875-5820,5755-5600 \mathrm{cal} \mathrm{BP}$ & -24.5 & KK47, East Pit excavation. ${ }^{\mathrm{h}}$ \\
\hline$\beta-56647$ & humic sandy clay & AMS & $398-399$ & $4470 \pm 70$ & $5315-4860 \mathrm{cal} \mathrm{BP}$ & - & Core $3{ }^{\mathrm{h}}$ \\
\hline$\beta-64124$ & sandy peat & radiometric $^{f}$ & $477-481$ & $4780 \pm 110$ & $5730-5300 \mathrm{cal} \mathrm{BP}$ & -27.2 & Core $3{ }^{\mathrm{h}}$ \\
\hline$\beta-115786$ & Cordia fruit & AMS & $375-385$ & $4700 \pm 50$ & $5585-5310 \mathrm{cal} \mathrm{BP}$ & -23.9 & KK47, East Pit excavation. ${ }^{\mathrm{h}}$ \\
\hline$\beta-115785$ & Cordia fruit & AMS & $495-505$ & $4980 \pm 50$ & $5890-5805,5770-5605$ cal BP & -23.7 & KK46.5, East Pit excavation. ${ }^{\mathrm{h}}$ \\
\hline$\beta-115787$ & Cordia fruit & AMS & $355-365$ & $5010 \pm 50$ & $5900-5620 \mathrm{cal} \mathrm{BP}$ & -23.4 & JJKK46, East Pit excavation. ${ }^{.}$ \\
\hline$\beta-115783$ & Cordia fruit & AMS & $475-485$ & $5030 \pm 50$ & $5910-5645 \mathrm{cal} \mathrm{BP}$ & -23.5 & KK46.5, East Pit excavation. ${ }^{.}$ \\
\hline$\beta-128627$ & Cordia fruit & AMS & $672-673$ & $5020 \pm 70$ & $5920-5605$ cal BP & -24.3 & Core $6{ }^{\mathrm{h}}$ \\
\hline$\beta-115784$ & Cordia fruit & AMS & $425-435$ & $5120 \pm 50$ & $5945-5740$ cal BP & -24.1 & KK46.5, East Pit excavation. ${ }^{h}$ \\
\hline$\beta-93000$ & sandy peat & AMS & $832-836$ & $5860 \pm 50$ & $6760-6545 \mathrm{cal} \mathrm{BP}$ & -28.4 & Core $6{ }^{\mathrm{h}}$ \\
\hline$\beta-128625$ & marine bivalve & AMS & $600-630$ & $6550 \pm 90^{\mathrm{g}}$ & $7190-6660$ cal BP & -0.3 & II45, East Pit excavation. ${ }^{\mathrm{h}}$ \\
\hline$\beta-128628$ & clay & AMS & 899-901 & $8520 \pm 80$ & 9580-9425 cal BP & -24.7 & Core $6 .^{\mathrm{h}}$ \\
\hline$\beta-128629$ & silty clay & AMS & $944-946$ & $8490 \pm 80$ & $9560-9405,9345-9320 \mathrm{cal} \mathrm{BP}$ & -24.3 & Core $6{ }^{\mathrm{h}}$ \\
\hline \multicolumn{8}{|l|}{ Silver Falls } \\
\hline$\beta-141062$ & humic clay & AMS & 130 & $6310 \pm 70$ & 7410-7020 cal BP & -26.9 & \\
\hline$\beta-148087$ & sandy clay & AMS & $355-356$ & $8160 \pm 40$ & 9250-9010 cal BP & -25.8 & Base of core. \\
\hline \multicolumn{8}{|c|}{ Wahiawa Bog } \\
\hline$\beta-149722$ & peat & AMS & $34-35$ & $5940 \pm 60$ & $6900-6650$ cal BP & -27.7 & \\
\hline$\beta-149723$ & peat & AMS & $114-115$ & $3800 \pm 40$ & $4290-4080 \mathrm{cal} \mathrm{BP}$ & -26.3 & Stratigraphic reversal. \\
\hline$\beta-148088$ & humic silty clay & AMS & $486-487$ & $23,090 \pm 180$ & Too old to calibrate & -29.7 & Base of core. \\
\hline
\end{tabular}

${ }^{\mathrm{a} D e p t h}$ in $\mathrm{cm}$ below datum in excavations, and $\mathrm{cm}$ below surface in cores.

${ }^{\mathrm{b} C}$ Corrected for isotopic fractionation.

'Based on Stuiver et al. (1998).

${ }^{\mathrm{d} D a t e}$ rejected. Sediments in this unit contain old carbon derived from erosion of channelized lake basin. See Burney et al. (2001) for details.

${ }^{\mathrm{e}}$ Gelatin fraction of Rattus exulans pelvis. Insoluble residue (probably sediment-derived organic acids) dated to $3038 \pm 60 \mathrm{yr} \mathrm{BP}(\mathrm{NZA} 10132), \delta^{13} \mathrm{C}=23.9$.

fSmall sample, given $4 \times$ normal counting time.

${ }^{\mathrm{g}}$ Applied local reservoir correction for marine samples (Stuiver and Braziunas 1993) of $115 \pm 50 \mathrm{yr}$. 


\section{APPENDIX 2}

\section{STRATIGRAPHIC DESCRIPTIONS}

\section{Limahuli Bog}

Coring reached a depth of $615 \mathrm{~cm}$ (Figure 2). From the surface down to $189 \mathrm{~cm}$, the sediment is an unconsolidated mat of plant detritus, darkening in color and becoming denser downwards. It becomes fully consolidated as a very coarse fibrous black N2.5/ peat at about $189 \mathrm{~cm}$. The peat continues down to $210 \mathrm{~cm}$, becoming silty near the bottom. From $210-214 \mathrm{~cm}$, the peat is interrupted by a layer of dark grayish brown $(2.5 \mathrm{Y} 4 / 2)$ fine basalt gravel. Somewhat finer black peat, with a clay component, resumes below this level, down to $232 \mathrm{~cm}$, where another gravel layer occurs. This one is thicker (from 232-240 cm), a mottled dark olive brown (2.5Y 3/3) to black humic peaty gravel, with angular pieces of basalt to $5 \mathrm{~mm}$.

At $240-250 \mathrm{~cm}$, and probably in the $50 \mathrm{~cm}$ not recovered below this, there are large tree trunks in the deposit. The $10 \mathrm{~cm}$ piece recovered was a very hard, dense reddish gray (7.5R 3/1) dicotyledonous wood containing pyrite cubes and framboids and plant rootlets. The wood layer was difficult to hammer through, and some material was lost below this level because the coring pipe was plugged by this dense wood, which dates to $1470 \pm 60 \mathrm{BP}(440-670$ cal AD).

Coring resumed at $300 \mathrm{~cm}$, recovering a $5 \mathrm{~cm}$-thick layer of fine gravel mixed with a peaty loam, ranging in color from dark gray $5 \mathrm{Y} 4 / 1$ to weak red $10 \mathrm{R} 5 / 4$. From $305-329 \mathrm{~cm}$ is a very dark gray 7.5 YR 3/1 humic silt. Below this level, down to $507 \mathrm{~cm}$, sediments are a coarse fibrous black N 2.5/ peat. Much of the fiber and pollen present is derived from grasses and sedges, with a strong representation of fern stems and spores as well. Graminoid leaves near the top of this unit, at $351 \mathrm{~cm}$, dated to $3910 \pm 60 \mathrm{BP}(4515-4465,4450-4155 \mathrm{cal} \mathrm{BP})$. A ${ }^{14} \mathrm{C}$ date from graminoid leaves at $466-$ $470 \mathrm{~cm}$ dated to $5140 \pm 60 \mathrm{yr} \mathrm{BP}(5995-5740 \mathrm{cal} \mathrm{yr} \mathrm{BP})$.

A dark olive brown $2.5 \mathrm{Y} 3 / 3$ silty clayey peat extends from $507-546 \mathrm{~cm}$. This unit becomes sandier and lighter in color near the bottom. A wood date from the base of this unit at $541-545 \mathrm{~cm}$ was 5410 \pm 50 yr BP (6295-6195, 6070-6020 cal yr BP). From 546-568 there is a dark olive brown 2.5 Y $3 / 3$ humic silty sand with basalt gravel and stones to $2 \mathrm{~cm}$. The basalt is highly vesicular, with a thick yellow weathering rind. The gravel is interrupted by a $4 \mathrm{~cm}$ thick band of dark olive brown $2.5 \mathrm{Y} 3 / 3$ humic sandy silty clay. From $572-603 \mathrm{~cm}$ is humic sandy silty gravel of the same color, with basalt stones to $3 \mathrm{~cm}$. This is followed by a $5 \mathrm{~cm}$ thick layer of humic silty clay. A ${ }^{14} \mathrm{C}$ age was obtained, from pretreated bulk sediments at 604-608 cm in this layer, of $8420 \pm 70 \mathrm{yr}$ BP (9535-9280 cal yr BP).

Coring was terminated on a layer of dark olive brown 2.5Y 3/3 coarse gravel 608-615 cm deep, with vesicular subrounded basalt stones to $3 \mathrm{~cm}$. Further progress was stopped by the density of the underlying material.

\section{Anini Beach}

From the modern surface to $5 \mathrm{~cm}$, the sediments are a dark reddish brown $5 \mathrm{YR} 3 / 2$ humic loamy sand with European-introduced snails (e.g. Subulina octona), pig teeth, kukui nuts (Aleurites moluccana), and marine shell fragments. Near the base of this unit, a few extinct endemic snails are present, notably Leptachatina sp. From $5-15 \mathrm{~cm}$, the European-introduced snails are less prevalent and there are more species of extinct endemics, including Orobophana sp. The sand matrix is coarser and less humic, with subangular cobbles of coralline rock. At about $15-25 \mathrm{~cm}$, a sandy matrix of reddish brown 5YR 4/4 contains indurated lumps of dark brown clay and a dense accumu- 
lation of Carelia cochlea and other extinct land snails, but introduced snails and marine shells are notably absent. A single $C$. cochlea shell, from $20-25 \mathrm{~cm}$ below datum, that showed no evidence in SEM for recrystallization or exogenous carbonates and retained a significant amount of protein (Ron Hatfield, Beta Analytic, pers. comm.), was selected for dating. AMS determination on the acid-etched shell yielded an age of $1840 \pm 50$ BP (70-260, 290-320 cal AD).

From $25-50 \mathrm{~cm}$, sediments are a coarse light olive brown $2.5 \mathrm{Y}$ 5/3 sand with many C. cochlea and other endemic snails, with several fruits of Pandanus tectorius. Near the base of this unit, sediments grade to a light yellowish brown $2.5 \mathrm{Y} 6 / 3$ sand with a decreasing concentration of terrestrial snails. From $50-70 \mathrm{~cm}$, the base of the profile, a light gray $2.5 \mathrm{Y} 7 / 2$ coarse sand contains marine shells and coralline cobbles, from subrounded to angular, and no terrestrial snails.

\section{Alekoko Fishpond}

The surficial sediments in the Alekoko core are a dark grayish-brown (2.5Y 3/2) humic silty clay (muck) with many rootlets and small gastropod shells (cf. Assiminea sp.) of a type that thrives in brackish and fresh waters of the island. The modern surface of this sediment is subject to benthic infaunal burrowing, weak tidal action, turbation by wind-driven currents, and disturbance by gill-net poles. A photograph of the pond taken about 1934, reproduced in Ching et al. (1973) shows the pond shoaling in many places, including the vicinity of the coring site, so a small amount of dredging may have occurred at some time since then, unless the photo was taken on an unusually low tide.

This unconsolidated sediment changes gradually at about $50 \mathrm{~cm}$ below surface (Figure 4) to much denser material that is likely to be less disturbed. This unit is a black (2.5Y 2.5/1) silty clayey peat, containing a larger component of plant fibers and algal skeletons, including many types of euryhaline-adapted and marine diatoms. Gastropod shells become less prevalent downwards, and, beginning at about $75 \mathrm{~cm}$, they are virtually replaced by shells of estuarine bivalves, including a small mussel (Mytilus sp.). The sediments of this type continue with little change down to $186 \mathrm{~cm}$, where there is a layer of wood fragments about $3 \mathrm{~cm}$ thick. This material is fibrous dicot fragments that appear to be deposited wood, and not in situ roots. This wood dated to $580 \pm 30 \mathrm{BP}(1305-1420 \mathrm{cal}$ yr AD).

The black silty clayey peat is again interrupted at $201-204 \mathrm{~cm}$, this time by calcareous grainstone fragments, including a subangular piece of aeolianite $3 \mathrm{~cm}$ in diameter. A date within the peat at $278-279 \mathrm{~cm}$ yielded an age of $2850 \pm 70 \mathrm{yr}$ BP (3195-2785 cal yr BP). The peat continues down to $312 \mathrm{~cm}$, gradually becoming slightly lighter in color (5Y 2.5/2 olivaceous black). At this level, bivalve fragments noticeably increase, and the sediment coarsens to a gravelly sandy peat of the same color, with clasts of subrounded molluscan conglomerate to $3 \mathrm{~cm}$ diameter, particularly around $320 \mathrm{~cm}$. At $323 \mathrm{~cm}$ the sediment changes abruptly to a very dark gray (5Y 3/1) clayey peat generally lacking shell fragments and coarse clastics. At $332 \mathrm{~cm}$ the sediment returns to humic gravelly sandy peat with molluscan fragments and conglomerate clasts, as described above. This type of sediment persists to the bottom of the core at $351 \mathrm{~cm}$ below the sediment surface. Dating of sediment from $346-347 \mathrm{~cm}$ yielded an age of 3,230 $\pm 70 \mathrm{BP}(3620-3340 \mathrm{cal} \mathrm{BP})$.

\section{Huleia Valley}

From the surface to the water table at $55 \mathrm{~cm}$, the sediment is a reddish-brown $5 Y \mathrm{R} 4 / 4$ silty clay. Near the base of this unit there are well-preserved seeds of indigenous plants, including the shrub Exocarpos luteolus, which is today a rare species found only in a few interior montane locations (Wagner et al. 1999). A mottled zone follows down to $70 \mathrm{~cm}$, where the sediment becomes a more 
uniform olive-gray $5 \mathrm{Y} 4 / 2$ sandy silty clay, changing to very dark gray $5 \mathrm{Y} 4 / 1$ sandy silt at $90 \mathrm{~cm}$. At $135 \mathrm{~cm}$ there is a distinct change to very dark gray $5 \mathrm{YR} 3 / 1$ humic sand, similar to the presumably prehuman sediments at about $200 \mathrm{~cm}$ depth in Alekoko Fishpond. The sediment becomes darker and more organic downwards, but less consolidated and more sandy below $200 \mathrm{~cm}$. From 298 to $326 \mathrm{~cm}$ the sediment is finer, a dark reddish gray 5 YR 4/2 peaty silty clay. Sediment from $325-326 \mathrm{~cm}$ yielded an age of $2790 \pm 40 \mathrm{BP}(2970-2780 \mathrm{cal} \mathrm{BP})$. Below $326 \mathrm{~cm}$ the sediment changes abruptly to basaltic subrounded gravel to $4 \mathrm{~cm}$, with pebbles of red sandstone.

\section{Lawai Kai}

The top $173 \mathrm{~cm}$ of the LAK-3 core is light brownish gray 10YR 6/2 sand with marine shell fragments, coral rubble, and basalt clasts (Figure 7). According to local sources (W Kikuchi, personal communication), the pond was maintained at about this depth (presumably by hand dredging) until 1946, when the largest historically recorded tsunami on the island struck the site, depositing a mixture of marine sediments and terrestrial rubble. The pond was further infilled by finer material, mostly sand and plant fibers, (typical of the top about $50 \mathrm{~cm}$ of the core) by Hurricanes 'Iwa (1982) and 'Iniki (1992).

An abrupt transition occurs at about $173 \mathrm{~cm}$ below surface. At this level, which may have been the depth of dredged maintenance prior to 1946, there is a "salt and pepper" sand (light-colored grains of calcareous sand mixed with darker volcanic sand grains and fine macroscopic particles of organic matter). There is good reason to believe that these sediments are from prehistoric times, as they contain shells of medium-sized endemic terrestrial snails such as Leptachatina cf. fossilis, which at Maha 'ulepu is abundant in early Polynesian times but completely absent from European-aged (post1778) sediments (Burney et al. 2001). From 177-192 cm there is a layer of very dark gray 2.5Y 3/1 silty peat (very similar to the material that accumulated in Alekoko Fishpond soon after its inferred time of construction about $600 \mathrm{BP}$ ). From the base of this peat at $192 \mathrm{~cm}$ down to $256 \mathrm{~cm}$ there is a dark brown 7.5YR 3/3 humic sand with pieces of brown vesicular basalt and endemic terrestrial snails, including the large Cyclamastra cf. cyclostoma, believed to have been extirpated at Maha'ulepu very early in the Polynesian period or before (Burney et al. 2001). This layer is interrupted at $233 \mathrm{~cm}$ by a thin (about $1 \mathrm{~cm}$ ) band of black $\mathrm{N} 2 / 0$ peat.

From $256 \mathrm{~cm}$ to $357 \mathrm{~cm}$, the stratigraphy is extremely complex, best described as a laminated sequence, composed of subunits each generally $<10 \mathrm{~cm}$ thick and in seemingly random order, of salt-and-pepper sand, humic silt, sandy peat, molluscan gravel, and diatomaceous saproprel. This type of sedimentary structure was noted at approximately the same depth in the Maha'ulepu sequence (designated there as Unit V), that yielded ${ }^{14} \mathrm{C}$ ages from $1241 \mathrm{cal} \mathrm{AD}$ near the top to 4380 cal BP near the bottom, and was interpreted as brackish-water organic deposits periodically interrupted by storm surges (Burney et al. 2001).

From $357-416 \mathrm{~cm}$ the deposit is a more uniform grayish brown $2.5 \mathrm{Y} 5 / 2$ humic sand with plant fibers, underlain by a very dark brown $2.5 \mathrm{Y} 3 / 2$ diatomaceous sapropel with plant fibers from 416$427 \mathrm{~cm}$. From $427-537 \mathrm{~cm}$ is a black 7.5 YR $2 / 1$ sandy silty clay, mottled with salt-and-pepper sand and containing shells of an estuarine mussel (Mytilus sp.). This massive unit becomes browner and more silty downwards, to $7.5 \mathrm{YR} 3 / 2$. Transition is gradual at the bottom of this unit, becoming dark grayish brown 2.5 YR 4/0 humic sand, containing plant fibers, radiolarians, formaminifera, and shell fragments of Mytilus and a marine crab. This humic sand unit with marine fossils continues down to the base of the core at $654 \mathrm{~cm}$. An AMS date on the pretreated sediments from 646-650 was $5300 \pm 80 \mathrm{BP}(6280-5910 \mathrm{cal} \mathrm{BP})$. 


\section{Kekupua Fishpond}

From 0-40 $\mathrm{cm}$ below the sediment surface, the coring site (KEK-3) yielded black (N 2/0) sapropel (Figure 8). This material contains an abundant and diverse diatom assemblage, including species in the genera Nitzschia, Melosira, Pinnularia, and Fragilaria. Plant fibers, fungus spores, and pollen (particularly grasses and sedges) are well-preserved.

At about $40 \mathrm{~cm}$, the sediment changes to a very dark grayish-brown (10YR 3/2) silty clay. Diatoms are less abundant and not so well-preserved, and organic material in general is more scarce. This silty clay changes gradually at about $80 \mathrm{~cm}$ to a dusky red (2.5YR 3/2) with fewer coarse clastics and a noticeable increase in microscopic charcoal. Sand grains increase in the silty clay at about $130 \mathrm{~cm}$, where the color darkens again to very dark grayish-brown (10YR 3/2). This material is more humic than the clay layers above it.

From 140-170 cm, the sediment is a very dark gray (10YR 3/1) sandy silty peat with large pieces of plant fiber and leaf tissue. The top of this unit $(140-150 \mathrm{~cm})$ was AMS dated to $830 \pm 50 \mathrm{BP}(1050$ 1095, 1140-1280 cal AD). A "key" (drupe) from a hala fruit (Pandanus tectorius) was extracted from the zone of contact between this unit and the one described below. It was dated by the standard radiometric technique, with $4 \times$ normal counting time to improve precision, to $980 \pm 80 \mathrm{BP}$ (8951225 cal AD).

At about $170 \mathrm{~cm}$, the sediment changes abruptly to a dark brown (10YR 3/3) silty sand containing large centric diatoms, sponge spicules, and foraminiferan tests of probable marine origin. Some wood-derived charcoal particles are present at this level. This sand layer coarsens downwards, becoming gravelly at about $200 \mathrm{~cm}$. Stones to $5 \mathrm{~cm}$ diameter were recovered from the base of the section, at $220 \mathrm{~cm}$. These were subrounded vesicular basalt.

\section{Silver Falls Ranch}

From the surface to $30 \mathrm{~cm}$, the sediment is a dark grayish brown 10Y4/1 clayey peat, grading into a dark greenish gray $10 \mathrm{G} 3 / 1$ peaty silty clay with subangular rock fragments, a soft white tephra (Figure 9). In the top $15 \mathrm{~cm}$ of this unit there are large pieces of well-preserved wood from Metrosideros and Pandanus. Some of this appears charred. From about $30-65 \mathrm{~cm}$ the sediment is a greenish gray $10 Y$ 5/1 humic clay with many roots, some recognizable as Pandanus, and flecks of the rock described above. From this depth down to $157 \mathrm{~cm}$, the clay retains the same color but becomes increasingly sandy. Pretreated sediments from $130 \mathrm{~cm}$ yielded a ${ }^{14} \mathrm{C}$ date of $6310 \pm 70 \mathrm{BP}(7410-$ 7020 cal BP).

At $135 \mathrm{~cm}$ there was a nodule of pale yellow $7.5 \mathrm{Y} 7 / 3$ sandy silty clay on top of well-preserved grass stems. Mottling with pale yellow sediments is present from this point down to $157 \mathrm{~cm}$, where a $3 \mathrm{~cm}$ band of plant fibers including possible Pandanus roots is present. From 160-204 cm the sediments are again a mottled silty sandy clay, mostly greenish gray $10 \mathrm{Y} 5 / 1$ but with light to dark brown nodules of sand. Below this level down to about $245 \mathrm{~cm}$ the sediments are similar but a darker color, dark greenish gray 10Y 4/1. Mottling increased downwards, and from $245 \mathrm{~cm}$ to a sharp transition at $293 \mathrm{~cm}$ the sediments are a strongly mottled humic silty clay, the modal color dark yellowish brown 10YR 4/6 ranging to yellow 10YR 7/6 and brown 10YR 4/3. Cracks in the rather dry sediments at this level show rust-colored iron stains. At $293 \mathrm{~cm}$, the sediment changes abruptly to a more uniform reddish yellow 7.5YR 6/8 humic clay. At $355 \mathrm{~cm}$ a change to a strong brown 7.5YR 4/6 silty sandy clay is also abrupt. An AMS date on the pretreated sediments from $355-356 \mathrm{~cm}$ (base of the core) yielded an age of $8160 \pm 40 \mathrm{BP}(9250-9010 \mathrm{cal} \mathrm{BP})$. At least $1 \mathrm{~m}$ of 
viscous clay sediment extends below this level, but piston-cable failure resulted in the loss of this sample.

\section{Kilohana Crater}

From the surface down to $25 \mathrm{~cm}$, the sediments are a brown 10YR 4/3 humic silty clay, becoming lighter in color downwards (Figure 10). At $25 \mathrm{~cm}$ there is an abrupt change to pale brown 10YR 6/ 3 humic clay. At $80 \mathrm{~cm}$ the sediment is a dark brown 10YR 3/3 peaty clay with highly humified wood. At $125 \mathrm{~cm}$ this changes to a very dark brown 10YR $2 / 2$ humified peat with much wood and dead roots. About $160 \mathrm{~cm}$ this becomes a dark grayish brown 10YR 4/2 clayey peat that persists to at least $200 \mathrm{~cm}$. Below this level, the unconsolidated nature of these very wet sediments made it impossible to sample further with the auger, but probing with a steel rod showed that soft sediments continued to $280 \mathrm{~cm}$, where either rock or very indurated hardpan was encountered. Near the top of this unit, at $170 \mathrm{~cm}$, an AMS date was obtained, the oldest reached so far on the island, of 26,020 \pm $230 \mathrm{BP}$ (too old for calibration).

\section{Wahiawa Bog}

From the surface down to $26 \mathrm{~cm}$, the sediment is a black 10YR 2/1 peat (Figure 11). This changes gradually to a very dark gray 10YR 3.5/1 silty clayey peat between $26-36 \mathrm{~cm}$. A sample from 34$35 \mathrm{~cm}$ dated by AMS to $5940 \pm 60 \mathrm{BP}(6900-6650 \mathrm{cal} \mathrm{BP})$. A gray 10YR 5/1 clay with subangular pieces of tephra occurs between $36-54 \mathrm{~cm}$. From $54-85 \mathrm{~cm}$, there is a dark grayish brown $2.5 \mathrm{YR} 4 /$ 2 silty clay, becoming mottled below $85 \mathrm{~cm}$ with yellowish brown 10YR 5/6 crumbly dry clay, grading into a gray $10 \mathrm{YR} 5 / 1$ silt. At 102-116 there is a unit of black 10YR2/1 peat with an uneven lower surface. An AMS date on a sample from 114-115 cm yielded a date of $3800 \pm 40$ BP (4290-4080 cal BP). From 116-215 cm the sediment is gray 10YR 5/1 clayey silt, with a few pieces of subrounded tephra, and increasing mottling with yellowish gray 10YR 5/4 sandy silt in the lower part. The unit becomes increasingly hard and dry, forming a hardpan of brown 7.5YR 4/4 powdery dry silty clay between $215-217 \mathrm{~cm}$. The great difficulty hammering through indicates that there was considerably more of this, but it was too hard to take up in the core barrel. Instead, the pipe was plugged by this material, resulting in the loss of a total of about $125 \mathrm{~cm}$ of sediment in the bottom of this drive and the top of the next.

Normal coring resumed at $345 \mathrm{~cm}$, yielding a pale yellow $2.5 \mathrm{Y} 7 / 4$ sandy silty clay that continues down to $416 \mathrm{~cm}$. From this level down to $455 \mathrm{~cm}$ the sediment is a light olive brown $2.5 \mathrm{Y} 5 / 3$ sandy silty clay with small nodules of sandy material. From $455 \mathrm{~cm}$ to the base of the core at $490 \mathrm{~cm}$, the sediment becomes more organic, a dark gray $2.5 \mathrm{Y} 4 / 1$ humic silty clay with sand nodules in the upper part and some mottling in the lower. A sample from 486-487 cm was AMS dated to 23,090 \pm $180 \mathrm{BP}$ (too old to calibrate).

\section{Kilohana (Alakai Swamp)}

From the surface down to $80 \mathrm{~cm}$, the sediment is a reddish black 5R 2.5/1 peat with fine roots and graminoid leaves (Figure 12). The upper peat is coarse-textured, with preserved leaf structures, but it fines downward. Near the base of the peat unit, plant macrofossils are largely absent and the peat is extremely fine-grained and humified. AMS dating of the base of this unit, 76-80 cm, yielded an age of $5000 \pm 50 \mathrm{BP}(5895-5615 \mathrm{cal} \mathrm{BP})$.

Over the next $7 \mathrm{~cm}(80-87 \mathrm{~cm})$, the sediments make a gradual transition from black peat to gray $\mathrm{N}$ $6 / 0$ humic clay. The clay becomes increasingly silty downwards, to an abrupt transition at $110 \mathrm{~cm}$, where there is a $1.5 \mathrm{~cm}$ layer of black $\mathrm{N} 2 / 0$ peat. Below this thin peat layer, the gray humic silty clay 
resumes. This becomes increasingly viscous downwards. At $250-259 \mathrm{~cm}$, the clay layer is interrupted by a gravel made up of gleyed, subrounded, saprolitic basalt nodules to $3 \mathrm{~cm}$ diameter. Below this level, sediments return to humic silty clay, generally a lighter gray than above (N5/0). From $278-283 \mathrm{~cm}$, there is a layer of hard rounded clay nodules, of the same color as the overlying clay, and possibly derived from basalt weathering (although no basalt was found at this level) or deflation. Gray humic silty clay continues to the base of the core at $318 \mathrm{~cm}$. Coring was terminated by the stiffness of the clay below this level. The basal $4 \mathrm{~cm}$ produced an AMS date of 15,100 $\pm 80 \mathrm{BP}$ $(18,525-17,625$ cal BP). 